\title{
Chemical Forms of Mercury in Human Hair Reveal Sources of Exposure
}

\author{
Alain Manceau, ${ }^{*},{ }^{\dagger}$ Mironel Enescu,,${ }^{\dagger}$ Alexandre Simionovici, ${ }^{\dagger}$ Martine Lanson, ${ }^{\dagger}$ Maria \\ Gonzalez-Rey, ${ }^{\S}$ Mauro Rovezzi," Rémi Tucoulou," Pieter Glatzel," Kathryn L. Nagy, ${ }^{*, \perp}$ \\ Jean-Paul Bourdineaud*,\#
}

†ISTerre, Université Grenoble Alpes, CNRS, CS 40700, 38058 Grenoble, France.

¿Laboratoire Chrono Environnement, Université de Franche-Comté, CNRS, 25030 Besançon, France.

${ }^{\S}$ Laboratoire EPOC, Université de Bordeaux, CNRS, 33120 Arcachon, France.

"European Synchrotron Radiation Facility (ESRF), 71 Rue des Martyrs, 38000 Grenoble, France.

${ }^{\perp}$ Department of Earth and Environmental Sciences, MC-186, 845 West Taylor Street, University of Illinois at Chicago, Chicago, Illinois 60607, United States.

\#Institut Européen de Chimie et Biologie, Université de Bordeaux, CNRS, 2 rue Escarpit, 33607 Pessac, France.

"To whom correspondence should be addressed. E-mail: alain.manceau@univ-grenoble-alpes.fr; jean-paul.bourdineaud@u-bordeaux.fr; klnagy@uic.edu

Keywords: Mercury, hair, speciation, XANES, spectroscopy 


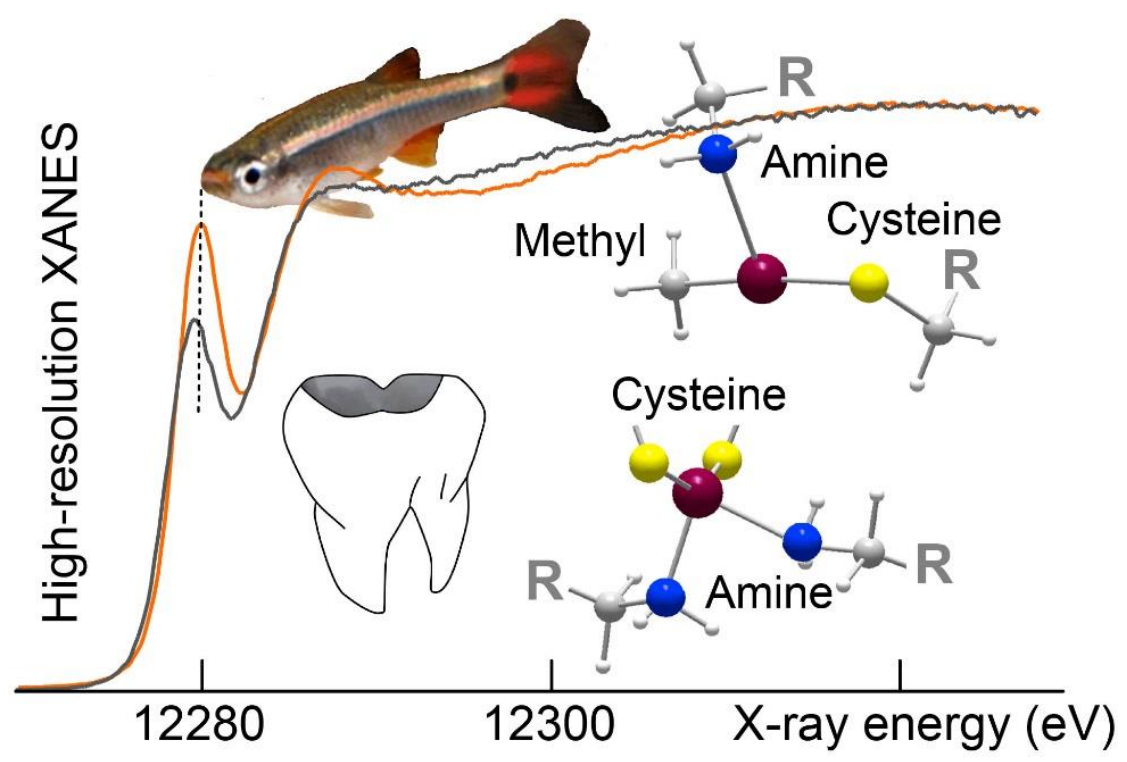

TOC image

\begin{abstract}
Humans are contaminated by mercury in different forms from different sources. In practice, contamination by methylmercury from fish consumption is assessed by measuring hair mercury concentration, whereas exposure to elemental and inorganic mercury from other sources is tested by analysis of blood or urine. Here, we show that diverse sources of hair mercury at concentrations as low as 0.5 parts per million can be individually identified by specific coordination to $\mathrm{C}, \mathrm{N}$, and $\mathrm{S}$ ligands with high energy-resolution X-ray absorption spectroscopy. Methylmercury from seafood, ethylmercury used as a bactericide, inorganic mercury from dental amalgams, and exogenously derived atmospheric mercury bind in distinctive intermolecular configurations to hair proteins, as supported by molecular modeling. A mercury spike located by X-ray nanofluorescence on one hair strand could even be dated to removal of a single dental amalgam. Chemical forms of other known or putative toxic metals in human tissues could be identified by this approach with potential broader applications to forensic and energy materials science.
\end{abstract}

\title{
INTRODUCTION
}


Nearly everyone is exposed to some form of mercury $(\mathrm{Hg})$, most commonly to highly neurotoxic methylmercury through consumption of fish ${ }^{1-3}$ Exposure of the general population may also occur via medical treatment with vaccines and other drugs that contain ethylmercury preservative, ${ }^{4}$ degradation of dental amalgams, ${ }^{5-7}$ or inhalation of $\mathrm{Hg}$ vapor from broken household objects such as fluorescent lamps. ${ }^{8}$ Occupational exposure is mainly to gaseous or dust forms of mercury. ${ }^{8-10}$ Mercury intake is monitored by measurement of $\mathrm{Hg}$ concentration in urine, blood, or scalp hair with hair being the common matrix analyzed for methylmercury. These measurements assess the total burden of mercury in individuals to diagnose poisoning and provide data for epidemiological studies, but cannot indicate the source of mercury essential for treatment and forensic investigation.

Recently, progress in identifying source was achieved with mercury isotopic analyses that show mass independent and mass dependent fractionations in hair indicative of exposure to methylmercury via coastal vs. freshwater fish consumption ${ }^{11,12}$ and to inorganic mercury via artisanal gold mining. ${ }^{13}$ However, isotopic measurements of hair require minimum concentrations above $1 \mathrm{ppm} \mathrm{Hg}$ which, in the general population, are typically reached by uptake of methylmercury from fish consumption; isotope ratios have not yet been able to identify inorganic mercury acquired from dental amalgams. ${ }^{14}$ Instead, characteristic isotopic ratios of this source were observed in urine from a cohort of dental professionals having ten or more amalgams. ${ }^{14}$ Urine samples in this study also had a second isotopic signature interpreted as methylmercury that was demethylated in the body. The concentration of $\mathrm{Hg}$ and amount of hair required for the isotopic analysis also precludes determination of the timing of a particular exposure event. Additionally, exogenous vs. endogenous exposure to inorganic mercury cannot be resolved. ${ }^{13}$

We explored how mercury is speciated in human scalp hair to determine if specific molecular forms could trace the source and timing of exposure. Speciation by conventional X-ray techniques ${ }^{15}$ is complicated by both the low concentration of mercury (typically 0.5 to $3 \mathrm{ng} \mathrm{Hg} / \mathrm{mg}$ hair ${ }^{16}$ ) and ambiguity in identifying coordinating ligands. ${ }^{17}$ Here, we show that the bonding environment of $\mathrm{Hg}$, including $\mathrm{C}, \mathrm{N}$, and $\mathrm{S}$ ligand identity, can be revealed at concentrations as low as $0.5 \mathrm{ng} \mathrm{Hg} / \mathrm{mg}$ hair by high energy-resolution X-ray absorption near-edge structure (HRXANES) spectroscopy. ${ }^{17,18}$ The data provide signatures of mercury source, distinguish exogenous vs. endogenous exposure to inorganic mercury, and in one instance, indicate the timing to within 1-2 days of an exposure event. 


\section{MATERIALS AND METHODS}

Sources of mercury in hair. We examined hair with a known dominant source of mercury in one of four forms: methylmercury (MeHg), ethylmercury (EtHg), elemental $\mathrm{Hg}\left(\mathrm{Hg}^{0}\right)$, and aqueous $\mathrm{Hg}\left(\mathrm{Hg}^{2+}\right)$ (Table 1). The mercury was incorporated either metabolically (in vivo) or exogenously (in vitro) (Supporting Information (SI) Sections S1 and S2.1).

Hair with high levels of mercury was obtained from two residents of the Amazonian state of Pará, Brazil (coded 1nMeHg13.8 and 2nMeHg10.6, labelling explained in Table 1 footnote) ${ }^{19}$ where exposure occurs mainly via consumption of fish from local contaminated rivers. ${ }^{3}$ Based on their reported diets, most mercury in their hair should be methylmercury. ${ }^{20}$ Hair with low $\mathrm{Hg}$ concentration was obtained from three residents of Grenoble, France with no known exposure to mercury besides average fish consumption (3nMeHg0.5, $4 \mathrm{nMeHg} 1.3,5 \mathrm{nMeHg} 1.3)$. A crosssectional profile of mercury in hair $(3 \mathrm{nMeHg} 0.5)$ by X-ray nanofluorescence (nano-XRF) showed uniform distribution in the cortex and medulla, confirming an endogenous origin (Figure 1a).

Hair contaminated by ethylmercury (EtHg) was prepared in vitro by treatment in solution with thimerosal (also known as thiomersal; 4xEtHg18.6, 5xEtHg18.7). Thimerosal is a fungicide and antiseptic added to some vaccines and drugs injected into the body. It hydrolyzes to thiosalicylic acid and EtHg, and EtHg reacts in the bloodstream with free cysteinyl thiol residues ( $\left.\mathrm{SR}^{-}\right)$from cysteine, hemoglobin and human serum albumin (HSA) to form EtHgSR adducts. ${ }^{4,21,22}$ Ethylmercury was identified by chromatographic-based methods in hair of vaccinated children. ${ }^{23}$

Elemental mercury as an in vivo source was assessed by examining hair from two other residents of France with dental amalgams. The first was exposed to mercury from October 2000 through June 2003 during removal of fillings and experienced subsequent chronic health effects (6nHg$\left.{ }^{0} 2.4\right)$. The $\mathrm{Hg}$ concentration near hair roots was $9.7 \mathrm{ng} / \mathrm{mg}$ in July 2003 and decreased to 2.4 $\mathrm{ng} / \mathrm{mg}$ in July 2014 when the hair was analyzed spectroscopically. The second person was exposed to mercury on 31 January 2013 during removal of a filling and the hair was cut on 24 May 2014 $\left(7 \mathrm{nHg}^{0} 0.74\right)$. Although the average $\mathrm{Hg}$ concentration in this hair was $0.2 \mathrm{ng} / \mathrm{mg}$, a $0.49 \mathrm{~mm}$ long hot-spot of $0.74 \mathrm{ng} / \mathrm{mg}$ was identified on a single strand by nano-XRF at a location that indicated a growth rate of $1.3 \mathrm{~cm}$ per month and a residence time of mercury in the bloodstream possibly no longer than one day (Figure 1b). In comparison, a mean half-time for EtHg of 5.6 days was 
measured in an adult treated with a thimerosal-preserved vaccine. ${ }^{24}$ The Hg-rich spot on another strand of hair was measured by HR-XANES.

The fourth source of mercury in hair is external contamination in the form of the divalent cation, which can result from oxidized mercury vapor in rainfall. ${ }^{25,26}$. This aqueous inorganic source of contamination was simulated in vitro in a 20 -day reaction $\left(4 \mathrm{xHg}^{2+} 15.3,5 \mathrm{xHg}^{2+} 12.4\right)$.

Nano-X-Ray Fluorescence. The transverse and longitudinal $\operatorname{Hg}(\operatorname{L} \alpha)$ profiles from Figure 1 were measured at room temperature on the undulator ID16B nanoprobe at the ESRF. ${ }^{27}$ The incident energy was $17.5 \mathrm{keV}$, and the X-ray beam focused to $50 \mathrm{x} 50 \mathrm{~nm}^{2}$ vertical x horizontal Full Width at Half Maximum (FWHM), using multilayer-coated Kirkpatrick-Baez optics. The total flux was $2 \times 10^{10}$ photons s $\mathrm{s}^{-1}$, and the counting time $45 \mathrm{sec}$ per pixel.

HR-XANES Spectroscopy. All $\mathrm{Hg} \mathrm{L}_{3}$-edge spectra were measured in high energy-resolution fluorescence yield detection mode with analyzer crystals on beamline ID26 at the European Synchrotron Radiation Facility (ESRF). Rejection of higher harmonics and reduction of heat load were achieved with a white beam Pd-coated, flat mirror working under total reflection at $2.5 \mathrm{mrad}$ deflecting angle. The incoming beam was monochromatized by the 111 reflection of a Si double crystal monochromator, then focused horizontally by a second Pd-coated mirror and vertically by a third Pd-coated mirror. The flux on the sample was approximately $10^{13}$ photons $\mathrm{s}^{-1}$ in a beam footprint of $\sim 700(\mathrm{H}) \times 80(\mathrm{~V}) \mu \mathrm{m}^{2} \mathrm{FWHM}$. The $\mathrm{Hg} \mathrm{L}_{\alpha 1}\left(3 \mathrm{~d}_{5 / 2} \rightarrow 2 \mathrm{p}_{3 / 2}\right)$ fluorescence line was selected using the 555 reflection of five spherically bent (radius $=0.5 \mathrm{~m}$ ) Si analyzer crystals (diameter $=100 \mathrm{~mm}$ ) aligned at an $81.8^{\circ}$ Bragg angle in a vertical Rowland geometry. The diffracted intensity was measured with a Si drift diode detector (SDD) in single photon counting mode. The effective energy resolution, obtained by convoluting the total instrument energy bandwidth (spreads of the incident and emitted rays), the SDD resolution $(\sim 160 \mathrm{eV})$, and the $3 \mathrm{~d}_{5 / 2}$ core-hole width from the $\mathrm{L}_{\alpha 1}$ line was about $3.0 \mathrm{eV}$, compared to an intrinsic line broadening of about $6.1 \mathrm{eV}$ in conventional fluorescence yield measurement with a solid-state detector. Spectra were collected at a temperature of $10-15 \mathrm{~K}$ and a scan time of $15 \mathrm{~s}$ to reduce exposure, and repeated at different pristine positions on the sample (except for $7 \mathrm{nHg}^{0} 0.74$ ) to increase the signal-to-noise ratio. Scans were monitored carefully for any evidence of radiation damage. The incident energy was scanned from $12260 \mathrm{eV}$ to $12360 \mathrm{eV}$ in $0.2 \mathrm{eV}$ steps. The high energy-resolution XANES spectra were normalized to unity at $\mathrm{E}=12360 \mathrm{eV}$. 
Computational Methodology. Our computational scheme was validated previously on a test set of combined X-ray structures and stabilities of Hg-thiolate complexes. ${ }^{17,28}$ Briefly, geometry optimizations were carried out using ORCA, version 3.0.3 ${ }^{29}$ at the second-order Møller-Plesset perturbation theory (MP2) ${ }^{30}$ level. The Ahlrichs polarized def2-TZVP basis sets and corresponding auxiliary basis sets def2-TZVP/ $\mathrm{C}^{31,32}$ of triple $\zeta$ quality ${ }^{33}$ were used throughout for all the atoms, in combination with the auxiliary def2-TZVP/ $/{ }^{34}$ Coulomb fitting basis to accelerate the MP2 calculations with the resolution of identity (RI) approximation. ${ }^{35,36}$ For Hg atoms, scalar relativistic effects were accounted for using the [OLD-SD(60,MDF)] effective core potential (ECP) ${ }^{37}$ as obtained from the Stuttgart pseudopotential library. The valence basis set used in connection with the ECP is based on a $(8 \mathrm{~s} 8 \mathrm{p} 6 \mathrm{~d} 1 \mathrm{f}) /[6 \mathrm{~s} 5 \mathrm{p} 3 \mathrm{~d} 1 \mathrm{f}]$ contraction scheme. In all calculations, the electrostatic contribution to solvation was introduced using the conductor-like screening model (COSMO) optimized for water solvation, ${ }^{38}$ as implemented in ORCA. ${ }^{39}$

Gibbs free energies $(G)$ of deprotonation were calculated on the optimized structures using Gaussian $09^{40}$ as follows:

$$
\Delta G=G\left(\mathrm{C}^{-}\right)+G\left(\mathrm{H}^{+}\right)-G(\mathrm{C})
$$

where $\mathrm{C}$ and $\mathrm{C}^{-}$denote the protonated and deprotonated $\mathrm{Hg}$-peptide complex, respectively, and $\mathrm{H}^{+}$the proton. For each complex, $G$ was evaluated from:

$$
G=E_{\text {Tot }}+\Delta G_{\text {corr }}
$$

where $E_{\text {Tot }}$ is the single point total electronic energy of the optimized structure, and $\Delta G_{\text {corr }}$ is the sum of the thermal and entropic corrections for $T=298 \mathrm{~K}$ and $p=1 \mathrm{bar}$. These corrections were evaluated analytically from a separate frequency calculation on the optimized structure. For comparison with experimental data, the $G(\mathrm{C})$ and $G\left(\mathrm{C}^{-}\right)$values were corrected for the difference between the standard-state concentrations in gas phase and in solution. The proton solvation energy was taken to be $-264.0 \mathrm{kcal} \mathrm{mol}^{-1}{ }^{41}$ Based on our previous ab initio study on $\mathrm{Hg}$-thiolate complexes, ${ }^{28}$ we estimate energetic variations to be precise to $2-3 \mathrm{kcal} \mathrm{mol}^{-1}$.

\section{RESULTS AND DISCUSSION}

Spectral signatures of mercury source. Differences among spectra of hair containing one dominant source of mercury result from distinct and identifiable mercury coordination structures (Figures 2 and S1a). The main absorption peak near $12280 \mathrm{eV}$ varies in intensity and position and is diagnostic of divalent mercury linearly coordinated ${ }^{17,18}$ to two thiol sulfur ligands if $\mathrm{Hg}$ is 
inorganic $\left(\mathrm{Hg}(\mathrm{SR})_{2}\right.$ complex $)$ or one thiol and one carbon ligand if $\mathrm{Hg}$ is organic (MeHgSR and EtHgSR) (Figure 3). Linear two-coordination, the most common geometry in mercury chemistry, occurs in biological systems ${ }^{42}$ and in complexes of mercury with cysteine (Cys), peptides, and proteins. ${ }^{43-46}$ This peak was expected in hair because $\alpha$-keratin ${ }^{47,48}$ and keratin-associated proteins (KAPs) ${ }^{49,50}$ are rich in cysteine residues. The variations in intensity and energy position indicate their potential for identifying signature structures of mercury source. Furthermore, hair contaminated exogenously revealed a distinct spectral pattern at higher X-ray energy, indicating ligands besides thiol sulfur and coordination numbers above two (Figure 2). Details of the ligand structures were obtained by comparing the hair spectra to those in a database for model compounds (SI Section S2.2). ${ }^{17,18}$

Mercury bonding. Methylmercury bonding is the same when assimilated into hair in vivo or in vitro (Figures $3 \mathrm{a}$ and $\mathrm{S} 1 \mathrm{~b}$ ), and in human serum albumin. The closest reference spectra are those for methylmercury L-cysteinate complexes (MeHgCys) at $\mathrm{pH} \geq 4.5$ (Figures $3 \mathrm{~b}$ and $\mathrm{S} 2$ ). These spectra have shallower minima and are shifted to the left in the energy range 12282-12286 eV (Figure 3b) compared to the spectrum for MeHgCys at $\mathrm{pH} 3$. These features are linked to the presence of next-nearest $\mathrm{N}$ ligands at $2.6 \AA$, beyond the nearest methyl (at $2.07 \AA$ ) and thiol (at $2.35 \AA$ ) ligands $\left(\mathrm{CH}_{3}-\mathrm{Hg}-\mathrm{SR}\right) .{ }^{17}$ Optimized molecular structures of the MeHgCys complex show that the protonated amine group $\left(\mathrm{NH}_{3}{ }^{+}\right)$is nonbonding at low $\mathrm{pH}$, one oxygen atom in the carboxylate group forms a weak contact at $2.86 \AA$, and the Me-Hg-S angle is $177^{\circ}$. At higher $\mathrm{pH}$, the $\mathrm{N}$ atom from the nonprotonated amine group bonds to $\mathrm{Hg}$ at $2.59 \AA$, making the $\mathrm{MeHgCys}$ complex a five-membered ring chelate through thiol $\mathrm{S}$ and amine $\mathrm{N}$ atoms with a $\mathrm{Me}-\mathrm{Hg}-\mathrm{S}$ angle bent to $171^{\circ}$ (Figure $3 \mathrm{~b}$ ). This coordination of mercury in hair is denoted $\mathrm{MeHg}[\mathrm{SR}+\mathrm{N}]$.

Ethylmercury bonds in hair are characterized only by a $-0.5 \mathrm{eV}$ shift of the near-edge peak relative to that for methylmercury bonds (1nMeHg13.8) (Figure 3c). This shift is caused by replacement of the methyl group by the ethyl group as verified by a XANES calculation for computed structures of the high-pH EtHgCys and MeHgCys complexes (Figure S3). This coordination of mercury in hair is designated $\mathrm{EtHg}[\mathrm{SR}+\mathrm{N}]$. In vivo addition should yield the same bonding by analogy with the identical spectra observed for endogenous ( $1 \mathrm{nMeHg} 13.8$, 2nMeHg10.6) and exogenous (4xMeHg30.2, 5xMeHg28.5) reaction of $\mathrm{MeHg}$ with hair (Figure S1b).

Hair mercury sourced from dental amalgams $\left(\mathrm{Hg}^{0}\right)$ shows features for coordination to two $\mathrm{S}$ 
and one or two $\mathrm{N}$ atoms $\left(\mathrm{Hg}\left[(\mathrm{SR})_{2}+\mathrm{N}_{1-2}\right]\right)$. The amplitude of the near-edge peak in $6 \mathrm{nHg}^{0} 2.4$ is relatively low which indicates greater deviation from linearity of the RS-Hg-SR angle, ${ }^{17}$ and the energy region just above this peak is shifted left which is evidence for $\mathrm{Hg}-\mathrm{N}$ bonding (Figure $3 \mathrm{~d}$ ). The amplitude of the near-edge peak for the $\mathrm{Hg}$ hot-spot $\left(7 \mathrm{nHg}^{0} 0.74\right)$ is reduced more because the thin hair sustained some radiation damage (Figure S4). However, this spectrum overall is highly similar to that of $6 \mathrm{nHg}^{0} 2.4$, suggesting that mercury initially had the same form in both samples. Geometry optimization shows that the RS-Hg-SR angle is smaller when the $\mathrm{Hg}-\mathrm{N}$ distance is shorter, similar to the relationship between the RS-Hg-SR angle and length of the opposite $\mathrm{Hg}-\mathrm{S}$ bond in $\mathrm{Hg}(\mathrm{SR})_{3} .{ }^{51}$ Here, this angle decreases from $171^{\circ}$ when the $\mathrm{N}$ atom is at $2.59 \AA$ (intramolecular $\mathrm{MeHg}[\mathrm{SR}+\mathrm{N}]$ coordination, Figure $3 \mathrm{~b}$ ), to $165^{\circ}$ when $\mathrm{N}$ is at $2.50-2.52 \AA$ (intramolecular $\mathrm{Hg}[\mathrm{SR}+\mathrm{N}]_{2}$ coordination, Figure $3 \mathrm{~d}$ ), and to $151^{\circ}$ when it is at $2.42-2.47 \AA$ (intermolecular $\mathrm{Hg}\left[(\mathrm{SR})_{2}+\mathrm{N}_{2}\right]$ coordination, Figure 4). A relationship between amplitude of the near-edge peak and presence of $\mathrm{Hg}-\mathrm{N}$ bonds is also supported by changes in the spectra of $\mathrm{Hg}(\mathrm{Cys})_{2}$ complexes with $\mathrm{pH}$. The intensity of the near-edge peak of $\mathrm{Hg}(\mathrm{Cys})_{2}$ continuously decreases as $\mathrm{pH}$ is raised from 3.0 ( $\mathrm{Hg}[\mathrm{SR}]_{2}$ coordination with nonbonding $\mathrm{NH}_{3}{ }^{+}$) to 11.5 $\left(\mathrm{Hg}[\mathrm{SR}+\mathrm{N}]_{2}\right.$ coordination) (Figure $\left.\mathrm{S} 2 \mathrm{~b}\right)$. The alignment of the near-edge peaks of $6 \mathrm{nHg}^{0} 2.4$ and EtHgCys, and higher energy regions of $6 \mathrm{nHg}^{0} 2.4$ and MeHgCys, suggests the presence of a minor amount of one or both alkylated species (Figure 2). For example, minor MeHg could originate both from amalgams and fish consumption. Zerovalent mercury in amalgams is oxidized by catalase in saliva to $\mathrm{Hg}^{2+}, 8$ of which some is alkylated by microbes ${ }^{52,53}$ and delivered to portal vein blood from the digestive tract. ${ }^{54}$

Hair samples exposed to aqueous $\mathrm{Hg}^{2+}\left(4 \mathrm{xHg}^{2+} 15.3\right.$ and $\left.5 \mathrm{xHg}^{2+} 12.4\right)$ have statistically identical spectra distinct from all others (Figures 2 and S1a). The near-edge peaks and trailing spectral edges are shifted left, and the signal immediately after the near-edge peak is shifted right. These changes indicate a mixture of species. An unconstrained linear combination fit to all reference spectra identified two components: $44 \pm 6 \% \mathrm{Hg}(\mathrm{Cys})_{2}$ complex at $\mathrm{pH} 6$ and $56 \pm 6 \%$ nanosized $\beta-\mathrm{HgS}$ (Figure 3e). The $\mathrm{pH} 6 \mathrm{Hg}(\mathrm{Cys})_{2}$ spectrum itself is a linear combination of $66 \%$ of the $\mathrm{pH} 3$ and $33 \%$ of the $\mathrm{pH} 11.5 \mathrm{Hg}(\mathrm{Cys})_{2}$ spectra representing protonated (no $\mathrm{Hg}-\mathrm{N}$ bond, linear RS-Hg-SR) and deprotonated (Hg-N bonds, bent RS-Hg-SR) forms, respectively (Figures $3 \mathrm{~d}$ and $\mathrm{S} 2 \mathrm{c})$. A two-component fit of $5 \mathrm{xHg}^{2+} 12.4$ using $\beta-\mathrm{HgS}$ and $\mathrm{pH} 11.5 \mathrm{Hg}(\mathrm{Cys})_{2}$ showed significant deviations between reconstructed and experimental spectra (Figure 3e), verifying that 
the $\mathrm{pH} 11.5$ structure is not a major form of mercury in the hair. In summary, hair exposed exogenously to aqueous $\mathrm{Hg}^{2+}$ produced nearly equal amounts of nanoparticulate mercury sulfide (nano $\beta-\mathrm{HgS}$ ) and a linear $\mathrm{RS}-\mathrm{Hg}-\mathrm{SR}$ complex with some $\mathrm{Hg}-\mathrm{N}$ bonding $\left(\mathrm{Hg}\left[(\mathrm{SR})_{2}+\mathrm{N}_{0-2}\right]\right.$ coordination).

Mercury binding sites. The endogenous forms of mercury observed in hair moved through the bloodstream to the hair follicle. Both $\mathrm{MeHg}$ and $\mathrm{EtHg}$ enter the follicle as $\mathrm{MeHgCys}$ or EtHgCys complexes by the L-type neutral amino acid carrier transport (LAT) system, which also carries these complexes into the brain. ${ }^{55,56}$ The LAT system recognizes the two organomercurials as molecular homologs of L-methionine. ${ }^{4,57}$ The primary observed form related to dental amalgams, $\operatorname{Hg}(\mathrm{Cys})_{2}$, can be carried by organic anion transporters OAT1 and OAT3, the amino acid transporter $b^{0,+},{ }^{58}$ or LAT1 and LAT2 ${ }^{59}$ Once in the follicle, all three forms of mercury bind to keratin and keratin-associated proteins (KAPs) that form the core of the growing hair. Exogenous $\mathrm{Hg}^{2+}$ diffuses through the hair cuticle into the cortex ${ }^{60}$ where it also binds, in part, to these proteins.

The observed mercury species involve nearest-neighbor bonding to thiol sulfur in amino acid residues. In keratin and KAPs, these residues contain 7 to $20 \%$ cysteine, $97-98 \%$ of which is crossbridged in S-S bonding as relatively inert cystine residue. ${ }^{47,48,61} \mathrm{We}$ confirmed that cystine is not an active binding site by comparing hair spectra with the spectrum for a $\mathrm{Hg}$-cystine reference compound (Figure S5). Thus, only the minor lone cysteine residues with free thiols exposed at the surface of the proteins must be reactive, ${ }^{48,62,63}$ as was proposed to explain the breakdown of the fibril structure of glycosaminoglycan in hair from an exposed population in a mercury mining district. ${ }^{64}$ These lone cysteine residues occupy the space between keratin intermediate filaments ${ }^{50}$ and can occur for instance at carboxy-termini of protein domains. ${ }^{49,50,65}$

The chemical structures of the mercury species were queried further to determine if protein binding sites are intramolecular or intermolecular by examining the bonds to nitrogen. The character of $\mathrm{MeHg}$ and EtHg binding is revealed by evaluating geometry-optimized structures that could have the observed $\mathrm{Hg}-\mathrm{N}$ bond length of $2.6 \AA$ (Figure 3). An intramolecular coordination to $\mathrm{S}$ and $\mathrm{N}$ atoms modeled with cysteine in protein is unfavorable because the cysteine nitrogen is coordinated to the backbone carbonyl oxygen from the peptide bond (R-CO-NH-R) (Figure 4a). Nitrogen is less nucleophilic in the amide (partial atomic charge - 0.6 e) than in the amine (-0.9 e) group, and therefore less reactive. The MeHg-NH distance of a Gly-Cys-Gly oligopeptide model 
is $2.96 \AA$, and the Me-Hg-S angle is $177.5^{\circ}$ (Figure 4a), compared to $2.59 \AA$ for $\mathrm{MeHg}-\mathrm{NH}_{2}$ and an angle of $171^{\circ}$ in the MeHgCys model with free cysteine (Figure 3b). Because palladium(II), platinum(II) and nickel(II) can dissociate the amide proton and coordinate to the deprotonated R$\mathrm{CO}-\mathrm{N}^{(-)}-\mathrm{R}$ peptide bond, ${ }^{66,67}$ we considered this as a possibility for anchoring $\mathrm{MeHg}$ chelation. Molecular orbital optimizations and natural population analysis ${ }^{17,68}$ show that $\mathrm{N}^{(-)}$has a charge of -0.7 e giving the $\mathrm{MeHg}\left[\mathrm{SR}+\mathrm{N}^{(-)}\right]$complex a favorable geometry with $\mathrm{Hg}-\mathrm{N}^{(-)}$bond distances of $2.5-2.7 \AA$ and a Me-Hg-S angle of $168^{\circ}-170^{\circ}$ (Figures S6a and S6b). However, the calculated Gibbs free energy for the deprotonation reaction $\mathrm{MeHg}\left[(\right.$ GlyCysGly) $] \rightarrow \mathrm{MeHg}\left[(\text { GlyCysGly) }]^{-1}\right.$ $+\mathrm{H}^{+}$of $24 \mathrm{kcal} / \mathrm{mol}$ and estimated $\mathrm{pK}_{\mathrm{a}}$ of 17 demonstrate that the $\mathrm{N}-\mathrm{H}$ bond is relatively stable (SI Section S3.1). Although termination of keratins and KAPs with an unbound cysteinyl $\mathrm{NH}_{2}$ group, as in the (N-terminal)Cys-Gly(C-terminal) model, would produce a $\mathrm{C}-\mathrm{Hg}-\mathrm{S}$ angle of $172^{\circ}$ and a $\mathrm{Hg}-\mathrm{NH}_{2}$ distance of $2.63 \AA$ (Figure S6c), these proteins are usually terminated with a methionine residue, not cysteine. ${ }^{49,63,65}$ Thus, the MeHg-N and EtHg-N bonds observed in the spectra are likely intermolecular involving side chains having nucleophilic $\mathrm{N}$ ligands. Optimized geometries of three possible $\mathrm{MeHg}[\mathrm{SR}+\mathrm{N}]$ coordination complexes with a side chain $\mathrm{NH}_{2}\left(-0.9\right.$ e) or guanidyl $\mathrm{NH}^{69}$ (-0.9 e) donor (Figures $4 \mathrm{~b}$ and S7) produced $\mathrm{Hg}-\mathrm{N}$ distances of $2.68 \AA$ to $2.75 \AA$, and an $\mathrm{Me}-\mathrm{Hg}$ $\mathrm{S}$ angle of $172^{\circ}$ to $174^{\circ}$, consistent with the HR-XANES results.

The coordination structures in hair contaminated through amalgam removal $\left(\mathrm{Hg}\left[(\mathrm{SR})_{2}+\mathrm{N}_{1-2}\right]\right)$ and external contact with $\mathrm{Hg}^{2+}\left(\mathrm{Hg}\left[(\mathrm{SR})_{2}+\mathrm{N}_{0-2}\right]\right)$ should also be intermolecular. Although the core $\mathrm{Hg}[\mathrm{SR}]_{2}$ linear coordination can occur either intra- or intermolecularly via protein folding and ligand docking, ${ }^{42,44,46}$ the bisphenoidal $\mathrm{Hg}\left[(\mathrm{SR})_{2}+\mathrm{N}_{2}\right]$ and tridentate $\mathrm{Hg}\left[(\mathrm{SR})_{2}+\mathrm{N}\right]$ coordinations must be obtained with side chain $\mathrm{NH}_{2}$ or guanidyl $\mathrm{NH}$ groups (Figure $4 \mathrm{c}$ ). Also, $\mathrm{Hg}^{2+}$ cannot dissociate the R-CO-NH-R peptide linkage to form intramolecular chelate rings with the deprotonated peptide nitrogen and sulfhydryl group (Figure S8). The $\Delta G$ of the deprotonation reaction calculated for $\mathrm{Hg}(\mathrm{SR})_{2}$ is $20 \mathrm{kcal} / \mathrm{mol}$, giving a $\mathrm{pK}_{\mathrm{a}}$ of 14.3 , again too high to break the $\mathrm{N}-\mathrm{H}$ bond at physiological pH (SI Section S3.2).

Mercury formed nanoparticulate $\beta-\mathrm{HgS}$ in hair exposed for 20 days to aqueous $\mathrm{Hg}^{2+}$ along with the $\left(\mathrm{Hg}\left[(\mathrm{SR})_{2}+\mathrm{N}_{0-2}\right]\right)$ coordination. This solid also forms from aged linear $\mathrm{Hg}(\mathrm{Cys})_{2}$ complexes at $\mathrm{pH} 4.5$ under ambient conditions in several weeks and from aged $\mathrm{Hg}(\mathrm{SR})_{2}$ in natural organic matter at pH 6 in a few days. ${ }^{18}$ We interpret the reaction in hair as partial transformation of the bis-(amino)thiolate complex $\left(\mathrm{Hg}\left[(\mathrm{SR})_{2}+\mathrm{N}_{0-2}\right]\right.$ coordination) based on similar rates observed 
in the natural organic matter experiments. ${ }^{18} \mathrm{~A}$ mixture of nanoparticulate $\alpha-\mathrm{HgS}$ and $\beta-\mathrm{HgS}$ was observed by electron microscopy in hair having a final $\mathrm{Hg}$ concentration approximately 50,000 times higher that had been contacted with $\mathrm{Ca}(\mathrm{OH})_{2}$ and $\mathrm{HgO}$ in water at $\mathrm{pH} 12.5$ for up to 15 days. ${ }^{60}$ Cystine was considered to release sulfur ${ }^{70}$ which then combined with mercury to form particles $7 \pm 2 \mathrm{~nm}$ in dimension in the central hair shaft. We propose two reasons for mercury aggregation at the much lower $\mathrm{pH}$ and hair $\mathrm{Hg}$ concentration in our study. One is that lone cysteine residues are distributed irregularly along the keratin and KAP strands in disordered, non-helical carboxy- and amino-terminal domains. ${ }^{47,49,71}$ These domains reside on the surface of the $\alpha$-helix filaments and are exposed to inwardly diffusing mercury. The second is the higher thermodynamic stability of $\mathrm{HgS}$ clusters in the condensed phase relative to $\mathrm{Hg}(\mathrm{Cys})_{2}$ complexes. ${ }^{17}$ Mercury atoms condense because of the metallophilic attraction of heavy elements with closed electron shells. ${ }^{72,73}$ Clusters of RS-[HgS $]_{n}$-SR form directly by thermodynamically driven association of $n \mathrm{Hg}(\mathrm{Cys})_{2}$ complexes and elimination of excess thiolate ligands. ${ }^{18}$

Identifying signature structures for mercury in hair was possible because subtle differences arising from $\mathrm{C}, \mathrm{N}$, and $\mathrm{S}$ ligands could be observed in XANES spectra at high energy-resolution and interpreted as bonds to amino acids in proteins using first principles calculations. Multiple species in one hair sample can be discerned with an appropriate reference database, and further refinement of exposure sources may benefit from complementary mercury isotope ratio measurements. Ripe for investigation by the spectroscopic approach are the organic and inorganic forms of other metals and metalloids that can be toxic above recommended intake levels (e.g., $\mathrm{Se}^{74}$ ), or are either known (e.g., $\mathrm{As}^{74}$ ) or putative (e.g., $\mathrm{Ag}^{75}$ ) toxins. When coupled with nanoimaging techniques, the timing of exposure events is also now possible to pinpoint in hair and other keratinaceous tissues such as human nails, ${ }^{76}$ which has potential implications for forensic investigation. ${ }^{77,78}$ The approach demonstrates capacity for extensive application to other trace metal systems including those involved in the extraction of energy critical elements from minerals, fly ash, and spent catalysts, and synthesis of materials.

\section{ASSOCIATED CONTENT}

\section{Supporting Information}


Detailed information on case reports of volunteers, hair and references, and Gibbs free energies of deprotonation of the amide group. This material is available free of charge via the Internet at http://pubs.acs.org.

\section{AUTHOR INFORMATION}

The authors declare no competing financial interests.

\section{ACKNOWLEDGEMENTS}

Support was provided to A.M, M.G-R., K.L.N., and J-P.B. by the French National Research Agency (ANR) under grant ANR-12-BS06-0008-01; to A.M., M.R., and P.G. by the ANR under grant ANR-10-EQPX-27-01 (EcoX Equipex); and, to K.L.N. and A.M. by the Office of Science (BER), U.S. Department of Energy, under grant DESC0001730, and the U.S. National Science Foundation under grant EAR-0952311. The Froggy platform of the CIMENT infrastructure (ANR grant ANR-10-EQPX-29-01) provided computing resources and Pierre Girard his expertise in parallel scientific processing.

\section{REFERENCES}

(1) McDowell, M. A.; Dillon, C. F.; Osterloh, J.; Bolger, P. M.; Pellizzari, E.; Fernando, R.; de Oca, R. M.; Schober, S. E., et al., Hair mercury levels in US children and women of childbearing age: Reference range data from NHANES 1999-2000. Environ. Health Persp. 2004, 112, 11651171.

(2) Mergler, D.; Anderson, H. A.; Chan, L. H. M.; Mahaffey, K. R.; Murray, M.; Sakamoto, M.; Stern, A. H., Methylmercury exposure and health effects in humans: A worldwide concern. Ambio 2007, 36, 3-11.

(3) Nevado, J. J. B.; Martin-Doimeadios, R. C. R.; Bernardo, F. J. G.; Moreno, M. J.; Herculano, A. M.; do Nascimento, J. L. M.; Crespo-Lopez, M. E., Mercury in the Tapajos River basin, Brazilian Amazon: A review. Environ. Intern. 2010, 36, 593-608.

(4) Dórea, J. G.; Farina, M.; Rocha, J. B. T., Toxicity of ethylmercury (and Thimerosal): a comparison with methylmercury. J. Appl. Toxicol. 2013, 33, 700-711.

(5) Mutter, J.; Naumann, J.; Guethlin, C., Comments on the article "The toxicology of mercury and its chemical compounds" by Clarkson and Magos (2006). Crit. Rev. Toxicol. 2007, 37, 537549. 
(6) Lindow, S. W.; Knight, R.; Batty, J.; Haswell, S. J., Maternal and neonatal hair mercury concentrations: the effect of dental amalgam. BJOG-Int. J. Obstet Gy. 2003, 110, 287-291.

(7) Fakour, H.; Esmaili-Sari, A.; Zayeri, F., Scalp hair and saliva as biomarkers in determination of mercury levels in Iranian women: Amalgam as a determinant of exposure. $J$. Hazard. Mater. 2010, 177, 109-113.

(8) Clarkson, T. W.; Vyas, J. B.; Ballatorl, N., Mechanisms of mercury disposition in the body. Am. J. Ind. Med. 2007, 50, 757-764.

(9) Feng, X.; Qiu, G., Mercury pollution in Guizhou, Southwestern China - An overview Sci. Tot. Environ. 2008, 400, 227-237.

(10) Li, P.; Feng, X. B.; Qiu, G. L.; Shang, L. H.; Wang, S. F., Mercury pollution in Wuchuan mercury mining area, Guizhou, Southwestern China: The impacts from large scale and artisanal mercury mining. Environ. Intern. 2012, 42, 59-66.

(11) Laffont, L.; Sonke, J. E.; Maurice, L.; Hintelmann, H.; Pouilly, M.; Bacarreza, Y. S.; Perez, T.; Behra, P., Anomalous mercury isotopic compositions of fish and human hair in the Bolivian Amazon. Environ. Sci. Technol. 2009, 43, 8985-8990.

(12) Li, M. L.; Sherman, L. S.; Blum, J. D.; Grandjean, P.; Mikkelsen, B.; Weihe, P.; Sunderland, E. M.; Shine, J. P., Assessing sources of human methylmercury exposure using stable mercury isotopes. Environ. Sci. Technol. 2014, 48, 8800-8806.

(13) Laffont, L.; Sonke, J. E.; Maurice, L.; Monrroy, S. L.; Chincheros, J.; Amouroux, D.; Behra, P., Hg speciation and stable isotope signatures in human hair as a tracer for dietary and occupational exposure to mercury. Environ. Sci. Technol. 2011, 45, 9910-9916.

(14) Sherman, L. S.; Blum, J. D.; Franzblau, A.; Basu, N., New insight into biomarkers of human mercury exposure using naturally occurring mercury stable isotopes. Environ. Sci. Technol. 2013, 47, 3403-3409.

(15) Harris, H. H.; Vogt, S.; Eastgate, H.; Legnini, D. G.; Hornberger, B.; Cai, Z.; Lai, B.; Lay, P. A., Migration of mercury from dental amalgam through human teeth. J. Synchrotron Radiat. 2008, 15, 123-128.

(16) Airey, D., Total mercury concentrations in human-hair from 13 countries in relation to fish consumption and location. Sci. Tot. Environ. 1983, 31, 157-180.

(17) Manceau, A.; Lemouchi, C.; Rovezzi, M.; Lanson, M.; Glatzel, P.; Nagy, K. L.; GautierLuneau, I.; Joly, Y., et al., Structure, bonding, and stability of mercury complexes with thiolate 
and thioether ligands from high-resolution XANES spectroscopy and first-principles calculations. Inorg. Chem. 2015, 54, 11776-11791.

(18) Manceau, A.; Lemouchi, C.; Enescu, M.; Gaillot, A.-C.; Lanson, M.; Magnin, V.; Glatzel, P.; Poulin, B. A., et al., Formation of mercury sulfide from $\mathrm{Hg}$ (II)-thiolate complexes in natural organic matter. Environ. Sci. Technol. 2015, 49, 9787-9796.

(19) Bourdineaud, J. P.; Durrieu, G.; Sarrazin, S. L. F.; da Silva, W. C. R.; Mourao, R. H. V.; de Oliveira, R. B., Mercurial exposure of residents of Santarem and Oriximina cities (Para, Brazil) through fish consumption. Environ. Sci. Pollut. Res. 2015, 22, 12150-12161.

(20) Harris, H. H.; Pickering, I. J.; G.N., G., The chemical form of mercury in fish. Science 2003, 301, 1203.

(21) Wu, X.; Liang, H.; O'Hara, K. A.; Yalowich, J. C.; Hasinoff, B. B., Thiol-modulated mechanisms of the cytotoxicity of thimerosal and inhibition of DNA topoisomerase II alpha. Chem. Res. Toxicol. 2008, 21, 483-493.

(22) Trümpler, S.; Lohmann, W.; Meermann, B.; Buscher, W.; Sperling, M.; Karst, U., Interaction of thimerosal with proteins-ethylmercury adduct formation of human serum albumin and $\beta$-lactoglobulin A. Metallomics 2009, 1, 87-91.

(23) Dórea, J. G.; Bezerra, V.; Fajon, V.; Horvat, M., Speciation of methyl- and ethyl-mercury in hair of breastfed infants acutely exposed to thimerosal-containing vaccines. Clin. Chim. Acta 2011, 412, 1563-1566.

(24) Barregard, L.; Rekic, D.; Horvat, M.; Elmberg, L.; Lundh, T.; Zachrisson, O., Toxicokinetics of mercury after long-term repeated exposure to thimerosal-containing caccine. Toxicol. Sci. 2011, 120, 499-506.

(25) Selin, N. E.; Jacob, D. J.; Park, R. J.; Yantosca, R. M.; Strode, S.; Jaegle, L.; Jaffe, D., Chemical cycling and deposition of atmospheric mercury: Global constraints from observations. J. Geophys. Res.-Atmos. 2007, 112.

(26) Akerblom, S.; Meili, M.; Bishop, K., Organic Matter in Rain: An Overlooked Influence on Mercury Deposition. Environ. Sci. Technol. Lett. 2015, 2, 128-132.

(27) Martinez-Criado, G.; Villanova, J.; Tucoulou, R.; Salomon, D.; Suuronen, J. P.; Laboure, S.; Guilloud, C.; Valls, V., et al., ID16B: a hard X-ray nanoprobe beamline at the ESRF for nanoanalysis. J. Synchrotron Radiat. 2016, 23, 344-352. 
(28) Enescu, M.; Manceau, A., High-level ab initio calculation of the stability of mercurythiolate complexes. Theor. Chem. Acc. 2014, 133, $\mathrm{n}^{\circ} 1457$.

(29) Neese, F., The ORCA program system. WIREs Comput. Mol. Sci. 2011, 2, 73-78.

(30) Møller, C.; Plesset, M. S., Note on an approximation treatment for many-electron systems. Phys. Rev. 1934, 46, 618-622.

(31) Schafer, A.; Horn, H.; Ahlrichs, R., Fully optimized contracted Gaussian-basis sets for atoms Li to Kr. J. Chem. Phys. 1992, 97, 2571-2577.

(32) Weigend, F.; Ahlrichs, R., Balanced basis sets of split valence, triple zeta valence and quadruple zeta valence quality for $\mathrm{H}$ to $\mathrm{Rn}$ : Design and assessment of accuracy. Phys. Chem. Chem. Phys. 2005, 7, 3297-3305.

(33) Schafer, A.; Huber, C.; Ahlrichs, R., Fully optimized contracted gaussian-basis sets of triple zeta valence quality for atoms Li to Kr. J. Chem. Phys. 1994, 100, 5829-5835.

(34) Weigend, F., Accurate Coulomb-fitting basis sets for H to Rn. Phys. Chem. Chem. Phys. 2006, $8,1057-1065$.

(35) Feyereisen, M.; Fitzgerald, G.; Komornicki, A., Use of approximate integrals in ab initio theory - An application in MP2 energy calculations. Chem. Phys. Lett. 1993, 208, 359-363.

(36) Kendall, R. A.; Fruchtl, H. A., The impact of the resolution of the identity approximate integral method on modern ab initio algorithm development. Theor. Chem. Acc. 1997, 97, 158163.

(37) Haussermann, U.; Dolg, M.; Stoll, H.; Preuss, H.; Schwerdtfeger, P.; Pitzer, R. M., Accuracy of energy-adjusted quasi-relativistic ab initio pseudopotentials - All electron and pseudopotential benchmark calculations for $\mathrm{Hg}, \mathrm{HgH}$ and their cations. Mol. Phys. 1993, 78, 1211 1224.

(38) Klamt, A.; Schuurmann, G., COSMO - A new approach to dielectric screening in solvents with explicit expressions for the screening energy and its gradient. J. Chem. Soc., Perkin Trans. 2 1993, 5, 799-805.

(39) Sinnecker, S.; Rajendran, A.; Klamt, A.; Diedenhofen, M.; Neese, F., Calculation of solvent shifts on electronic g-tensors with the conductor-like screening model (COSMO) and its self-consistent generalization to real solvents (Direct COSMO-RS). J. Phys. Chem. A 2006, 110, 2235-2245. 
(40) Frisch, M. J.; Trucks, G. W.; Schlegel, H. B.; Scuseria, G. E.; Robb, M. A.; Cheeseman, J. R.; Scalmani, G.; Barone, V., et al., Gaussian 09, Revision A.1. Gaussian, Inc., Wallingford CT. In 2009.

(41) Kelly, C. P.; Cramer, C. J.; Truhlar, D. G., Aqueous solvation free energies of ions and ion-water clusters based on an accurate value for the absolute aqueous solvation free energy of the proton. J. Phys. Chem. B. 2006, 110, 16066-16081.

(42) Lian, P.; Guo, H. B.; Riccardi, D.; Dong, A. P.; Parks, J. M.; Xu, Q.; Pai, E. F.; Miller, S. M., et al., X-ray structure of a $\mathrm{Hg}^{2+}$ complex of mercuric reductase (MerA) and quantum mechanical/molecular mechanical study of $\mathrm{Hg}^{2+}$ transfer between the $\mathrm{C}$-terminal and buried catalytic site cysteine pairs. Biochemistry 2014, 53, 7211-7222.

(43) Pufahl, R. A.; Singer, C. P.; Peariso, K. L.; Lin, S. J.; Schmidt, P. J.; Fahrni, C. J.; Culotta, V. C.; Penner-Hahn, J. E., et al., Metal ion chaperone function of the soluble $\mathrm{Cu}(\mathrm{I})$ receptor Atx 1. Science 1997, 278, 853-856.

(44) Wernimont, A. K.; Huffman, D. L.; Lamb, A. L.; O'Halloran, T. V.; Rosenzweig, A. C., Structural basis for copper transfer by the metallochaperone for the Menkes/Wilson disease proteins. Nature Str. Biol. 2000, 7, 766-771.

(45) Mah, V.; Jalilehvand, F., Glutathione complex formation with mercury(II) in aqueous solution at physiological pH. Chem. Res. Toxicol. 2010, 23, 1815-1823.

(46) Luczkowski, M.; Zeider, B. A.; Hinz, A. V. H.; Stachura, M.; Chakraborty, S.; Hemmingsen, L.; Huffman, D. L.; Pecoraro, V. L., Probing the coordination environment of the human copper chaperone HAH1: Characterization of $\mathrm{Hg}^{\mathrm{II}}$-bridged homodimeric species in solution. Chem. Eur. J. 2013, 19, 9042-9049.

(47) Fraser, R. D. B.; Macrae, T. P.; Sparrow, L. G.; Parry, D. A. D., Disulfide bonding in alphakeratin. Int. J. Biol. Macromol. 1988, 10, 106-112.

(48) Parry, D. A. D.; North, A. C. T., Hard alpha-keratin intermediate filament chains: Substructure of the N-and C-terminal domains and the predicted structure and function of the Cterminal domains of Type I and Type II chains. J. Str. Biol. 1998, 122, 67-75.

(49) Shimomura, Y.; Aoki, N.; Rogers, M. A.; Langbein, L.; Schweizer, J.; Ito, M., Characterization of human keratin-associated protein 1 family members. J. Invest. Dermatol. Symp. Proc. 2003, 8, (1), 96-99. 
(50) Parry, D. A. D.; Smith, T. A.; Rogers, M. A.; Schweizer, J., Human hair keratin-associated proteins: Sequence regularities and structural implications. J. Struc. Biol. 2006, 155, 361-369.

(51) Manceau, A.; Nagy, K. L., Relationships between $\mathrm{Hg}(\mathrm{II})-\mathrm{S}$ bond distance and $\mathrm{Hg}(\mathrm{II})$ coordination in thiolates. Dalton Trans. 2008, 11, 1421-1425.

(52) Heintze, U.; Edwardsson, S.; Derand, T.; Birkhed, D., Methylation of mercury from dental amalgam and mercuric-chloride by oral streptococci in vitro. Scand. J. Dent. Rese. 1983, 91, 150152.

(53) Leistevuo, J.; Leistevuo, T.; Helenius, H.; Pyy, L.; Osterblad, M.; Huovinen, P.; Tenovuo, J., Dental amalgam fillings and the amount of organic mercury in human saliva. Caries Res. 2001, 35, 163-166.

(54) Hahn, L. J.; Kloiber, R.; Vimy, M. J.; Takahashi, Y.; Lorscheider, F. L., Dental silver tooth fillings - A source of mercury exposure revealed by whole-body image scan and tissue-analysis. Faseb J. 1989, 3, 2641-2646.

(55) Zareba, G.; Cernichiari, E.; Goldsmith, L. A.; Clarkson, T. W., Validity of methyl mercury hair analysis: mercury monitoring in human scalp/nude mouse model. J. Appl. Toxicol. 2008, 28, 535-542.

(56) Zimmermann, L. T.; Santos, D. B.; Naime, A. A.; Leal, R. B.; Dórea, J. G.; Barbosa, F.; Aschner, M.; Rocha, J. B. T., et al., Comparative study on methyl- and ethylmercury-induced toxicity in C6 glioma cells and the potential role of LAT-1 in mediating mercurial-thiol complexes uptake. Neurotoxicology 2013, 38, 1-8.

(57) Yin, Z. B.; Jiang, H. Y.; Syversen, T.; Rocha, J. B. T.; Farina, M.; Aschner, M., The methylmercury-L-cysteine conjugate is a substrate for the L-type large neutral amino acid transporter. J. Neurochemi. 2008, 107, 1083-1090.

(58) Bridges, C. C.; Zalups, R. K., Molecular and ionic mimicry and the transport of toxic metals. Toxicol. Appl. Pharm. 2005, 204, 274-308.

(59) Cannon, V. T.; Zalups, R. K.; Barfuss, D. W., Amino acid transporters involved in luminal transport of mercuric conjugates of cysteine in rabbit proximal tubule. J. Pharmacol. Exp. Ther. 2001, 298, 780-789.

(60) Patriarche, G.; Walter, P.; Van Eslandre, E.; Ayache, J.; Castaing, J., Characteristics of HgS nanoparticles formed in hair by a chemical reaction. Phil. Mag. 2013, 93, 137-151. 
(61) Yu, J. L.; Yu, D. W.; Checkla, D. M.; Freedberg, I. M.; Bertolino, A. P., Human hair keratins. J. Invest. Dermatol. 1993, 101, S56-S59.

(62) Requejo, R.; Hurd, T. R.; Costa, N. J.; Murphy, M. P., Cysteine residues exposed on protein surfaces are the dominant intramitochondrial thiol and may protect against oxidative damage. Febs J. 2010, 277, 1465-1480.

(63) Lee, C. H.; Kim, M. S.; Chung, B. M.; Leahy, D. J.; Coulombe, P. A., Structural basis for heteromeric assembly and perinuclear organization of keratin filaments. Nature Struct. Mol. Biol. 2012, 19, 707-715.

(64) Xing, X. Q.; Du, R.; Li, Y. F.; Li, B.; Cai, Q.; Mo, G.; Gong, Y.; Chen, Z. J., et al., Structural change of human hair induced by mercury exposure. Environ. Sci. Technol. 2013, 47, 11214-11220.

(65) Strasser, B.; Mlitz, V.; Hermann, M.; Tschachler, E.; Eckhart, L., Convergent evolution of cysteine-rich proteins in feathers and hair. BMC Evol. Biol. 2015, 15, n 88.

(66) Sugiura, Y.; Hirayama, Y., Copper(II) and nickel(II) complexes of sulfhydryl and imidazole containing peptides - Characterization and a model for "blue" copper sites. J. Am. Chem. Soc. 1977, 99, 1581-1585.

(67) Sigel, H.; Martin, R. B., Coordinating properties of the amide bond - Stability and structure of metal-ion complexes of peptides and related ligands. Chem. Rev. 1982, 82, 385-426.

(68) Glendening, E. D.; Landis, C. R.; Weinhold, F., NBO 6.0: Natural bond orbital analysis program. J. Comput. Chem. 2013, 34, 1429-1437.

(69) Ratilla, E. M. A.; Scott, B. K.; Moxness, M. S.; Kostic, N. M., Terminal and new bridging coordination of methylguanidine, arginine, and canavanine to platinum(II) - The 1st crystallographic study of bonding between a transition-metal and a guanidine ligand. Inorg. Chem. 1990, 29, 918-926.

(70) Haveli, S. D.; Walter, P.; Patriarche, G.; Ayache, J.; Castaing, J.; Van Elslande, E.; Tsoucaris, G.; Wang, P. A., et al., Hair fiber as a nanoreactor in controlled synthesis of fluorescent gold nanoparticles. Nano Lett. 2012, 12, 6212-6217.

(71) Bowden, P. E.; Hainey, S.; Parker, G.; Hodgins, M. B., Sequence and expression of human hair keratin genes. J. dermatol. Sci. 1994, 7, S152-63. 
(72) Pyykko, P.; Straka, M., Ab initio studies of the dimers $\left(\mathrm{HgH}_{2}\right)_{2}$ and $\left(\mathrm{HgMe}_{2}\right)_{2}$. Metallophilic attraction and the van der Waals radii of mercury. Phys. Chem. Chem. Phys. 2000, 2, 2489-2493.

(73) Feng, Y. Q.; Cheng, L. J., Structural evolution of $\left(\mathrm{Au}_{2} \mathrm{~S}\right)_{n}(n=1-8)$ clusters from first principles global optimization. RSC Advances 2015, 5, 62543-62550.

(74) Weekley, C. M.; Aitken, J. B.; Witting, P. K.; Harris, H. H., XAS studies of Se speciation in selenite-fed rats. Metallomics 2014, 6, (12), 2193-2203.

(75) Sharma, V. K.; Siskova, K. M.; Zboril, R.; Gardea-Torresdey, J. L., Organic-coated silver nanoparticles in biological and environmental conditions: Fate, stability and toxicity. Adv. Colloid Interfac. 2014, 204, 15-34.

(76) Gherase, M. R.; Desouza, E. D.; Farquharson, M. J.; McNeill, F. E.; Kim, C. Y.; Fleming, D. E. B., X-ray fluorescence measurements of arsenic micro-distribution in human nail clippings using synchrotron radiation. Physiol. Meas. 2013, 34, 1163-1177.

(77) Kempson, I. M.; Henry, D.; Francis, J., Characterizing arsenic in preserved hair for assessing exposure potential and discriminating poisoning. J. Synchrotron Radiat. 2009, 16, 422 427.

(78) Bertrand, L.; Vichi, A.; Doucet, J.; Walter, P.; Blanchard, P., The fate of archaeological keratin fibres in a temperate burial context: microtaphonomy study of hairs from Marie de Bretagne (15th c., Orléans, France). J. Archaeol. Sci. 2014, 42, 487-499.

(79) Amaro-Estrada, J. I.; Ramirez-Solis, A., Aqueous microsolvation of $\mathrm{HgClOH}$. A systematic MP2 study of the $\mathrm{HgClOH}-\left(\mathrm{H}_{2} \mathrm{O}\right)_{n}$ species with $n=1-4$. Comput. Theor. Chem. 2013, 1006, 47-51.

(80) Amaro-Estrada, J. I.; Maron, L.; Ramirez-Solis, A., Aqueous solvation of $\mathrm{HgClOH}$. Stepwise DFT solvation and Born-Oppenheimer molecular dynamics studies of the $\mathrm{HgClOH}$ $\left(\mathrm{H}_{2} \mathrm{O}\right)_{24}$ complex. Phys. Chem. Chem. Phys. 2014, 16, 8455-8464.

\section{FIGURE LEGENDS}

Figure 1. Distribution of mercury in hair by nano-XRF. (a) Transverse profile of mercury (arbitrary units) in a single strand from a healthy individual ( $3 \mathrm{nMeHg} 0.5$ ). Hair image is shown at a smaller scale than the profile. (b) Longitudinal profile from an individual contaminated by extraction of a dental amalgam $\left(7 \mathrm{nHg}^{0} 0.74\right)$. The mercury spike records the contamination event. 
Figure 2. Spectral signature of the form of mercury in hair by HR-XANES spectroscopy. Hair was exposed to methylmercury (1nMeHg13.8, black), ethylmercury (4xEtHg18.6, violet), inorganic mercury from dental amalgam $\left(6 \mathrm{nHg}^{0} 2.4\right.$, orange), and aqueous divalent mercury $\left(5 \mathrm{xHg}^{2+} 12.4\right.$, blue). Variations in near-edge peak amplitude and position (marked by dashed vertical line in the inset) at 12280-12290 eV, and post-edge shape, indicate that the structural form of $\mathrm{Hg}$ in hair differs and provides a source-specific tracer for identifying the origin of mercury.

Figure 3. Mercury coordination in hair derived from HR-XANES spectra. (a and b) Methylmercury $(\mathrm{MeHg})$ is bonded to a thiol sulfur $\left(\mathrm{SR}^{-}\right)$and a nitrogen atom in hair (1nMeHg13.8; 2nMeHg10.6; 4xMeHg30.2) as when complexed with human serum albumin (MeHg-HSA) or Lcysteine at pH 4.5 and above (MeHgCys). (c) Ethylmercury (EtHg) is also bonded to a thiol sulfur and a nitrogen atom in hair $(4 \mathrm{xEtHg} 18.6)$, as is thimerosal complexed with L-cysteine or HSA (THI-Cys and THI-HSA). (d) Endogenous inorganic mercury from dental amalgams $\left(6 \mathrm{nHg}^{0} 2.4\right)$ is bonded to two thiol sulfur and one or two nitrogen atoms in hair, as when complexed with Lcysteine at and above physiological $\mathrm{pH}$. At acidic $\mathrm{pH}$, the protonated amine group $\left(\mathrm{NH}_{3}{ }^{+}\right)$of Lcysteine is non-bonding, which is seen by a shift (arrow) to higher energy of the HR-XANES trace (green) beyond the intense near-edge peak. The dashed vertical line is a guide for the position of the near-edge peak. (e) Exogenous inorganic mercury, for example from the atmosphere, $\left(5 \mathrm{xHg}^{2+} 12.4\right)$ is in two forms: bonded to two thiol sulfurs, like with L-cysteine, and precipitated as nanoparticulate metacinnabar $(\beta-\mathrm{HgS})$. The schematic at right represents a reaction in which linear $\mathrm{Hg}(\mathrm{SR})_{2}$ units are transformed to $\beta-\mathrm{HgS}$. The $\mathrm{MeHg}(\mathrm{Cys})$ and $\mathrm{Hg}(\mathrm{Cys})_{2}$ complexes (b and d) were optimized by MP2/TZVP-ecp calculations. ${ }^{17,28,79,80}$ Bond lengths are in angstroms, and bond angles are in black. Dark red, Hg; yellow, S; blue, N; red, O; gray, C; light gray, H.

Figure 4. Geometry-optimized models of $\mathrm{Hg}$ binding sites in hair proteins (MP2/TZVP-ecp optimization). ${ }^{17}$ (a) Intramolecular $\mathrm{MeHg}$ and $\mathrm{EtHg}$ conformations yield long $\mathrm{Hg}-\mathrm{NH}$ distances incompatible with HR-XANES results. (b) Possible conformation of intermolecular MeHg binding environment from (A) with a guanidyl group (NH) from an arginine (Arg) side chain $(\mathrm{MeHg}[\mathrm{SR}+\mathrm{N}]$ coordination with $\mathrm{SR}=$ GlyCysGly). The mercury-nitrogen distance $(2.74 \AA)$ is shortened to well below the sum of the van der Waals radii (3.10 $\AA$ ) for the $\mathrm{Hg}-\mathrm{N}$ atomic pair. 
Two other conformations with amine groups from a lysine (Lys) and a LysGly side chain are depicted in Figure S6. (c) Possible intermolecular conformation of the bisphenoidal $\mathrm{Hg}\left[(\mathrm{SR})_{2}+\mathrm{N}_{2}\right]$ coordination of inorganic mercury which shortens the $\mathrm{Hg}-\mathrm{N}$ bonds (2.42 and $2.47 \AA$ ) further because $\mathrm{Hg}^{2+}$ is more electrophilic than $\mathrm{MeHg}^{+}$. The closer the $\mathrm{N}$ atom to mercury, the more the (Me/RS)-Hg-SR angle is bent, which is seen in HR-XANES by a lower amplitude of the near-edge peak. Bond lengths are in angstroms, and bond angles are in black. Dark red, Hg; yellow, S; blue, $\mathrm{N}$; red, O; gray, C; light gray, H. Atomic charges, in units of elementary charge e and calculated by natural population analysis (NPA) ${ }^{68}$, are in blue. 
Table 1. Source species and concentration of $\mathrm{Hg}$ in hair from seven volunteers as provided in sample codes*.

\begin{tabular}{llccc}
\hline Individual & \multicolumn{1}{c}{$\begin{array}{c}\mathrm{MeHg} \\
\left(\mathrm{CH}_{3} \mathrm{Hg}^{+}\right)\end{array}$} & $\begin{array}{c}\mathrm{EtHg} \\
\left(\mathrm{C}_{2} \mathrm{H}_{5} \mathrm{Hg}^{+}\right)\end{array}$ & $\mathrm{Hg}^{0}$ & $\mathrm{Hg}^{2+}$ \\
\hline$\# 1$ & 1nMeHg13.8 & & & \\
$\# 2$ & 2nMeHg10.6 & & & \\
$\# 3$ & 3nMeHg0.5 & & & $4 \mathrm{xHg}^{2+} 15.3$ \\
$\# 4$ & 4nMeHg1.3 & $4 \mathrm{xEtHg} 18.6$ & & \\
& 4xMeHg30.2 & & & $5 \mathrm{xHg}^{2+} 12.4$ \\
$\# 5$ & $5 \mathrm{nMeHg} 1.3$ & $5 \mathrm{xEtHg} 18.7$ & & \\
& $5 \mathrm{xMeHg} 28.5$ & & $6 \mathrm{nHg}^{0} 2.4$ & \\
$\# 6$ & & & $7 \mathrm{nHg}^{0} 0.74$ & \\
$\# 7$ & & & &
\end{tabular}

*Note. The first number of each sample code is the number of the individual, "n" refers to endogenous exposure and "x" to exogenous treatment, the next set of letters stand for the source species of mercury, and the last number is the concentration in $\mathrm{ng} \mathrm{Hg} / \mathrm{mg}$ hair dry weight. 

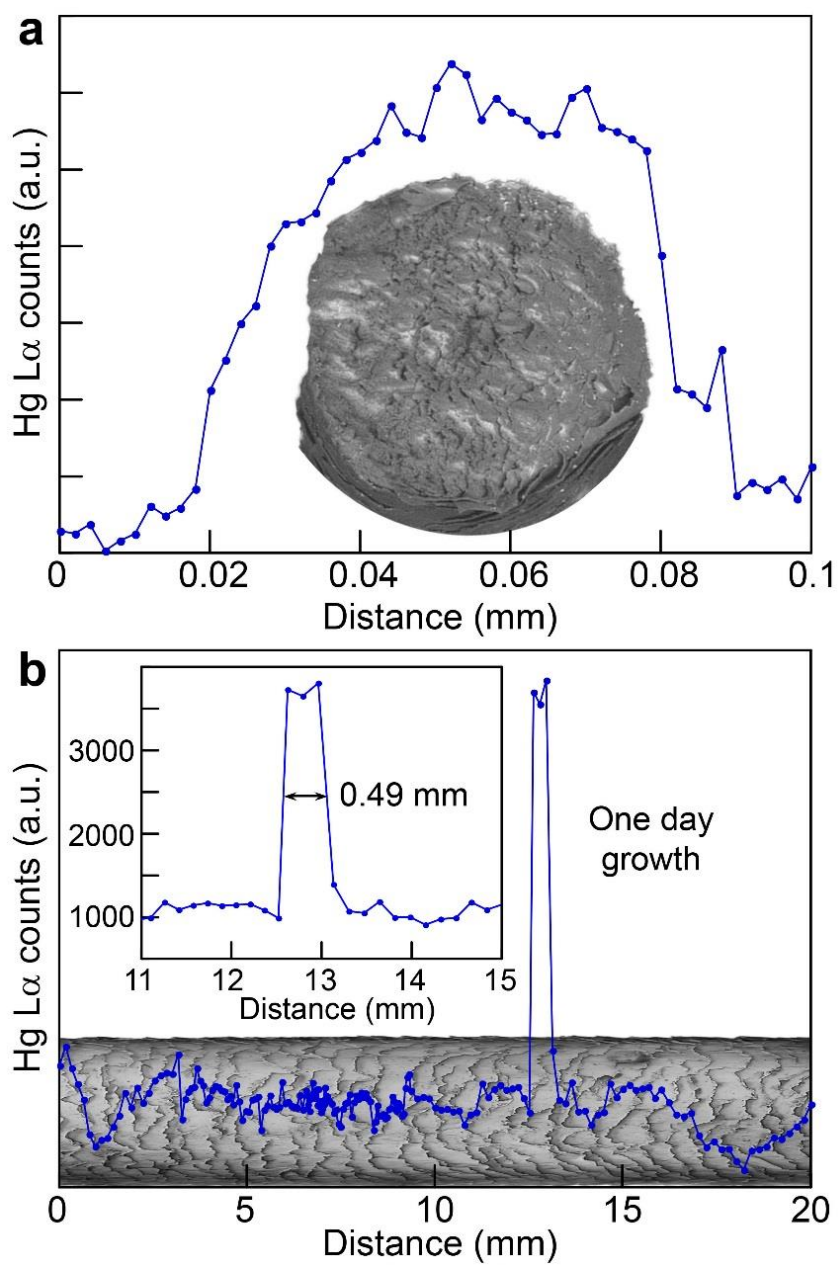

Figure 1

\section{Sensitivity of HR-XANES to the source of mercury}

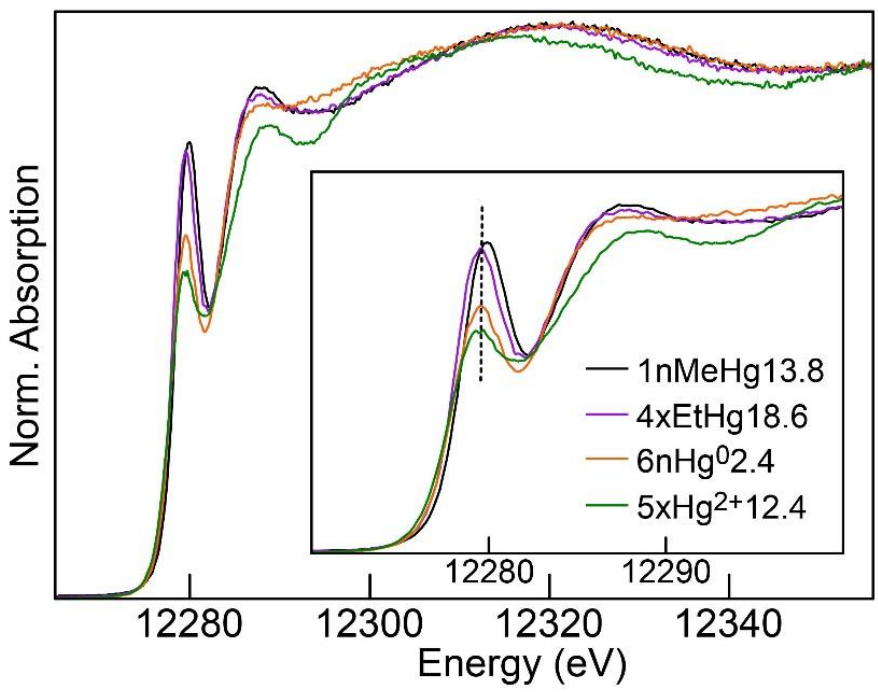

Figure 2 
Hair with cysteinyl ethylmercury (EtHgCys)
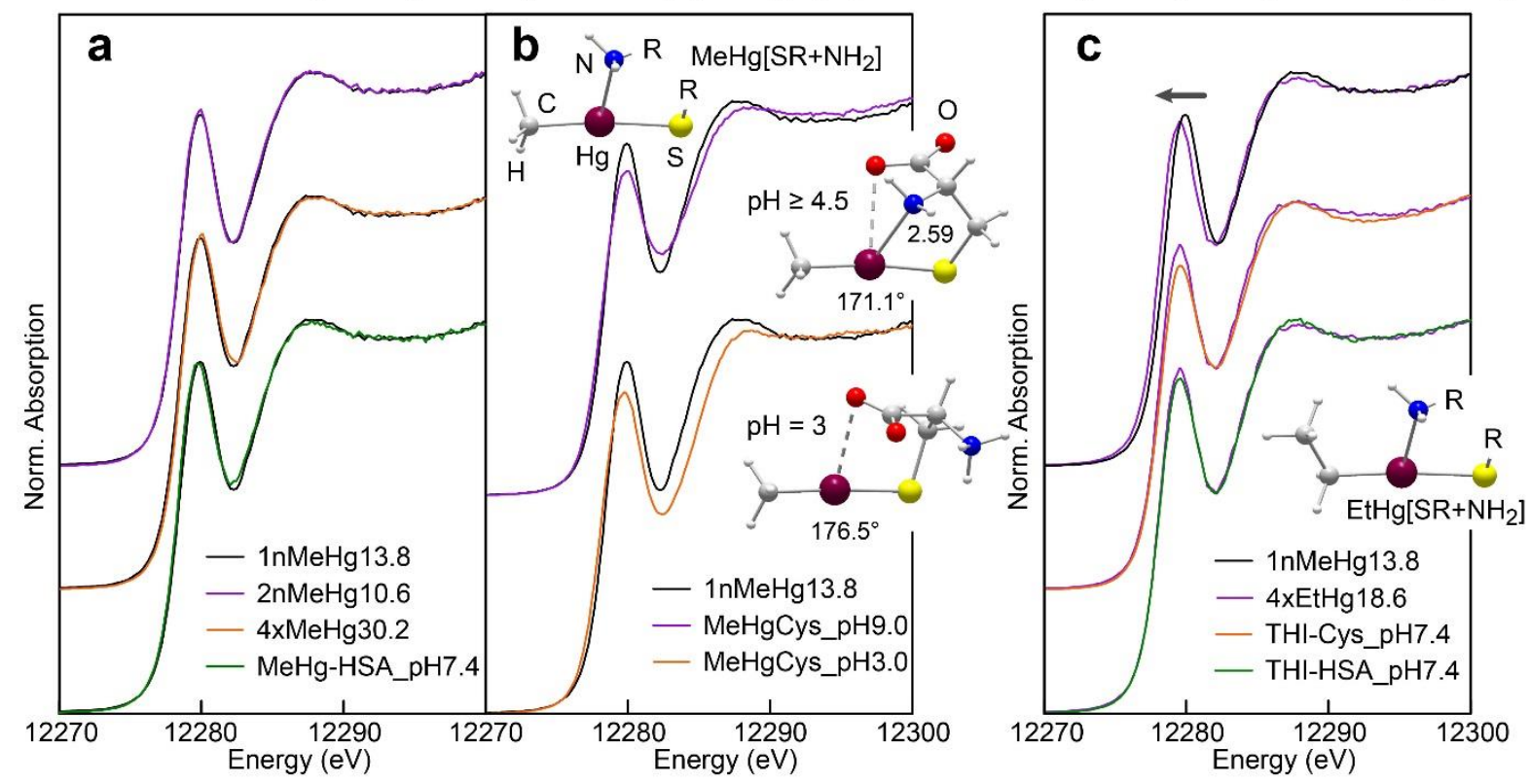

Hair with dicysteinylmercury $\left(\mathrm{Hg}(\mathrm{Cys})_{2}\right)$

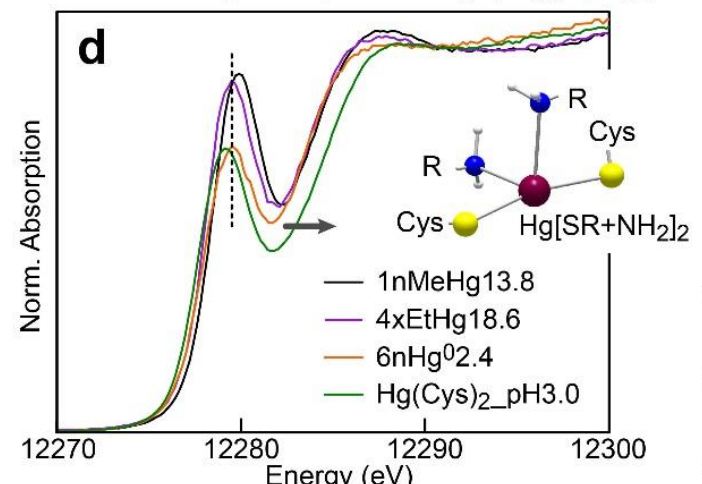

$\mathrm{Hg}(\mathrm{Cys})_{2}$ at low $\mathrm{pH}$

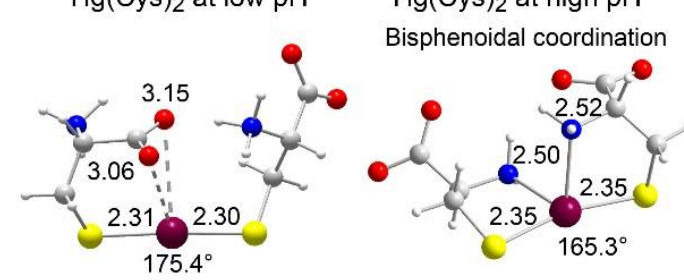

Hair with nanoparticulate $\beta$-HgS

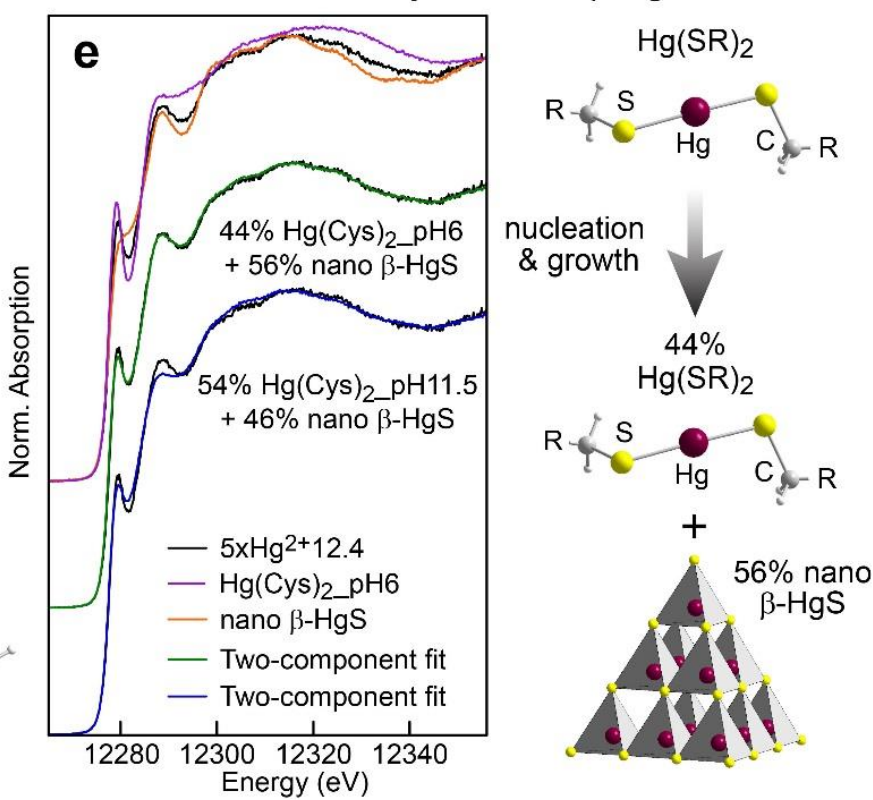

Figure 3 
Intramolecular MeHg binding site

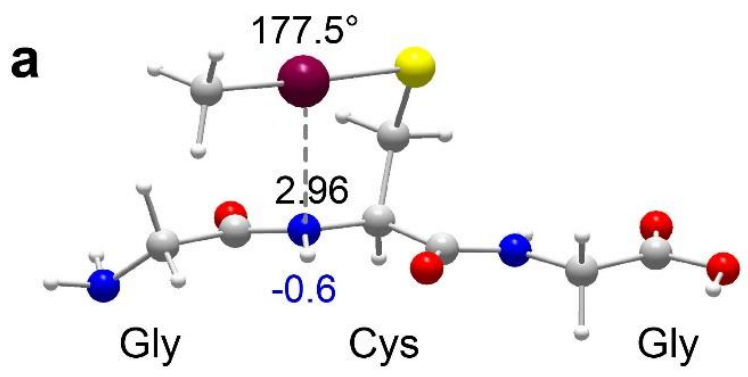

Intermolecular MeHg binding site

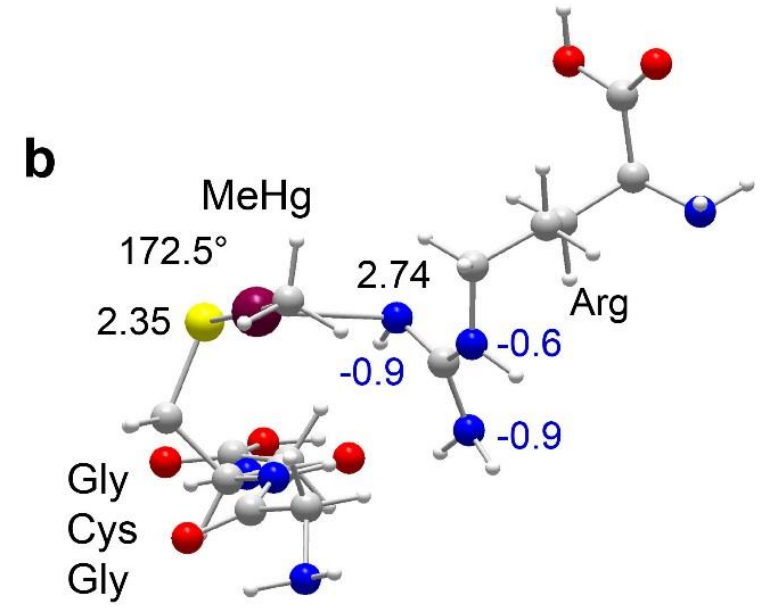

Intermolecular $\mathrm{Hg}$ binding site

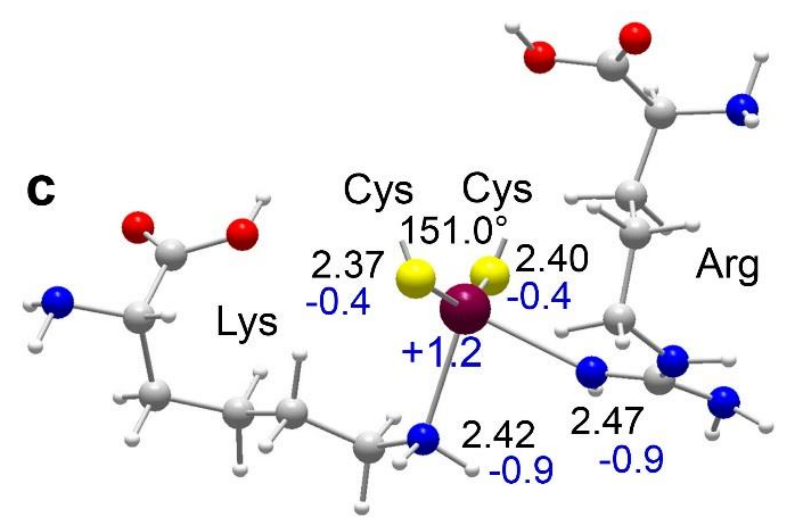

Figure 4 


\section{Supporting Information for}

\section{Chemical Forms of Mercury in Human Hair Reveal Sources of Exposure}

Alain Manceau, ${ }^{*}{ }^{\dagger}$ Mironel Enescu, ${ }^{\ddagger}$ Alexandre Simionovici, ${ }^{\dagger}$ Martine Lanson, ${ }^{\dagger}$ Maria Gonzalez-Rey, ${ }^{\S}$ Mauro Rovezzi, ${ }^{\|}$Rémi Tucoulou, ${ }^{\|}$Pieter Glatzel," Kathryn L. Nagy, ${ }^{*, \perp}$ JeanPaul Bourdineaud*,\#

†ISTerre, Université Grenoble Alpes, CNRS, CS 40700, 38058 Grenoble, France.

${ }^{\ddagger}$ Laboratoire Chrono Environnement, Université de Franche-Comté, CNRS, 25030 Besançon, France.

${ }^{\S}$ Laboratoire EPOC, Université de Bordeaux, CNRS, 33120 Arcachon, France.

"European Synchrotron Radiation Facility (ESRF), 71 Rue des Martyrs, 38000 Grenoble, France.

${ }^{\perp}$ Department of Earth and Environmental Sciences, MC-186, 845 West Taylor Street, University of Illinois at Chicago, Chicago, Illinois 60607, United States.

\#Institut Européen de Chimie et Biologie, Université de Bordeaux, CNRS, 2 rue Escarpit, 33607 Pessac, France.

Number of pages: 14

Number of Figures: 9

Number of Tables: 4 


\section{S1. Case reports of volunteers $1,2,6$, and 7 \\ S1.1. Individual \#1 (1nMeHg13.8)}

This volunteer was a 13-year old female student in a public school at the time of hair sampling (2010). She was living in Oriximiná in the state of Pará, Brazil, a city of 63,000 residents located along the banks of the Trombetas River $40 \mathrm{~km}$ upstream from its confluence with the Amazon River. She had no dental amalgams or hair treatment at the time of sampling, and her answers on a questionnaire indicated that the fish she was eating were purchased directly from fishermen who fished in the Trombetas River. The main species of fish she ate were mapará (Hypophthalmus sp., a planktivore) and pacú (Mylossoma duriventre, a frugivorous omnivore), and she consumed on average 10 meals per week of $400 \mathrm{~g}$ of fish per meal. The total amount of $\mathrm{Hg}$ in pacú sold in the nearby city of Santarém was monitored from October 2009 to June 2010, and had a range of 0.13 to $3.32 \mathrm{mg} \mathrm{Hg} / \mathrm{kg}$ fish flesh. ${ }^{1}$

\section{S1.2. Individual \#2 (2nMeHg10.6)}

This volunteer was a male of age 36 at the time of hair sampling (2010). He was living in Santarém in Pará, Brazil, a city of 299,000 residents located at the confluence of the Tapajós and Amazon Rivers. He had no dental amalgams or hair treatment at the time of sampling, and stated in a questionnaire that the fish he was eating were caught in the Tapajós River and purchased directly from fishermen. He specified neither the species of fish he was eating nor the amount of fish consumed per meal.

\section{S1.3. Individual \#6 (6nHg0 2.4)}

This person is a female who was 60 at the time of sampling in July 2014. She had undergone removal of 5 amalgams by unsafe procedures in October 2000 and then reported having various negative health symptoms. In February 2002, 3 more amalgams were removed without precautions. After suffering unpleasant to severe symptoms in the following months, sensitivity to multiple chemicals linked to the amalgam removals was suspected, and therefore she continued to have her blood, urine and hair analyzed periodically starting in November 2002 (Table S1). Two last amalgams were removed in June 2003. Besides mercury, several other toxic metals were analyzed in her hair including aluminum, antimony, arsenic, beryllium, bismuth, cadmium lead, platinum, thallium, thorium, uranium, nickel, silver, tin, and titanium. Only silver proved to be above the reference value $(0.15 \mathrm{ng} / \mathrm{mg})$ with concentrations of 0.65 on July 13, 2003 and 0.25 $\mathrm{ng} / \mathrm{mg}$ on January 28,2013 , respectively (medical laboratory data). It is worth noting that silver is the second metal in dental amalgams in terms of percentage just after mercury. The Hg burden in blood and hair is not linked to fish consumption because this person is aware of the risk of mercury contamination from fish: she eats on average less than $50 \mathrm{~g}$ of fish per week, selecting species known to contain a low amount of mercury.

Urinary porphyrins are good biomarkers of inhibition of the pathway for heme biosynthesis. The main enzymes inhibited by heavy metals are uroporphyrin decarboxylase and coproporphyrinogen oxidase, leading to an increase in coproporphyrin and pentacarboxyporphyrin in urine. ${ }^{2}$ Urinary porphyrins from individual \#6 were quantified in January 2003, May 2008, and 
May 2011 (Table S2). Results show elevated levels of coproporphyrins I and III as compared to reference values, indicating metal intoxication.

Table S1. Mercury concentration in blood, urine and hair of individual \#6.

\begin{tabular}{|c|c|c|c|}
\hline Date & Sample & Value & Laboratory $^{a}$ \\
\hline $14-11-2002$ & Blood & $54.0 \mathrm{ng} / \mathrm{mL}$ & LCL (Paris, France) \\
\hline 21-11-2002 & Urine ${ }^{b}$ & $\begin{array}{l}2.5 \mathrm{ng} / \mathrm{mL} \\
7.4 \mathrm{ng} / \mathrm{mg} \text { creatinine }\end{array}$ & ToxiLabo (Nantes, France) \\
\hline $8-1-2003$ & Blood & $38.9 \mathrm{ng} / \mathrm{mL}$ & LCL \\
\hline $8-1-2003$ & Urine & $\begin{array}{l}2.3 \mathrm{ng} / \mathrm{mL} \\
6.8 \mathrm{ng} / \mathrm{mg} \text { creatinine }\end{array}$ & LCL \\
\hline $12-2-2003$ & Blood & $19.1 \mathrm{ng} / \mathrm{mL}$ & LCL \\
\hline $14-7-2003$ & Hair & $9.7 \mathrm{ng} / \mathrm{mg}$ & $\begin{array}{l}\text { Doctor's data (St. Charles, IL, } \\
\text { USA) }\end{array}$ \\
\hline $23-12-2003$ & Urine & $\begin{array}{l}2.9 \mathrm{ng} / \mathrm{mL} \\
6.4 \mathrm{ng} / \mathrm{mg} \text { creatinine }\end{array}$ & ToxiLabo \\
\hline $24-6-2005$ & Hair & $5.3 \mathrm{ng} / \mathrm{mg}$ & Doctor's data \\
\hline $24-6-2008$ & Hair & $4.7 \mathrm{ng} / \mathrm{mg}$ & Doctor's data \\
\hline $5-11-2008$ & Blood & $13.0 \mathrm{ng} / \mathrm{mL}$ & ToxiLabo \\
\hline $12-2-2009$ & Blood & $9.0 \mathrm{ng} / \mathrm{mL}$ & $\begin{array}{l}\text { Laboratoire Pasteur Cerba } \\
\text { (Cergy-Pontoise, France) }\end{array}$ \\
\hline $17-8-2011$ & Blood & $12.0 \mathrm{ng} / \mathrm{mL}$ & ToxiLabo \\
\hline $17-12-2011$ & Blood & $11.2 \mathrm{ng} / \mathrm{mL}$ & $\begin{array}{l}\text { Laboratoire CERBA (Puteaux, } \\
\text { France) }\end{array}$ \\
\hline $21-12-2011$ & Blood & $10.6 \mathrm{ng} / \mathrm{mL}$ & ToxiLabo \\
\hline 28-1-2013 & Hair & $3.1 \mathrm{ng} / \mathrm{mg}$ & Doctor's data \\
\hline $20-4-2013$ & Blood & $9.0 \mathrm{ng} / \mathrm{mL}$ & Cerba (Puteaux, France) \\
\hline 7-7-2014 & Hair & $2.4 \mathrm{ng} / \mathrm{mg}$ & $\begin{array}{l}\text { Arcachon Marine Station } \\
\text { This work }\end{array}$ \\
\hline
\end{tabular}

Table S2. Urinary porphyrins of individual \#6 (in $\mathrm{nmol} / \mathrm{g}$ creatinine). ${ }^{\mathrm{a}}$

\begin{tabular}{|c|c|c|c|}
\hline \multirow[b]{3}{*}{ Porphyrins ${ }^{b}$} & \multicolumn{3}{|c|}{ Date } \\
\hline & $28-1-2003$ & $31-5-2008$ & $25-5-2011$ \\
\hline & & & \\
\hline uP (9-15) & 5 & 14 & 8 \\
\hline $7 \operatorname{cxP}(2-4)$ & 1.8 & 4.4 & 3.4 \\
\hline $6 \mathrm{cxP}(0.2-0.8)$ & 0.6 & 1.3 & 0.3 \\
\hline $5 \mathrm{CXP}(1.5-3.5)$ & 4.4 & 3.1 & 4.0 \\
\hline pcP $(3-7)$ & 20.6 & 11 & 14 \\
\hline $\mathrm{CP}(60-120)$ & 248 & 243 & 218 \\
\hline
\end{tabular}

\footnotetext{
${ }^{a}$ Analyses performed by Laboratoire Philippe Auguste, Paris, France.

b uP: uroporphyrins I and III; 7cxP: heptacarboxyporphyrin; 6cxP: hexacarboxyporphyrin; 5 cxP: pentacarboxyporphyrin; pcP: precoproporphyrin; CP: coproporphyrins I and III.

The reference concentrations in human populations are indicated in parentheses and are expressed as ranges calculated as means \pm 2 SD.
} 


\section{S1.4. Individual \#7 (7-Hg0.74)}

This person is a female of age 51 at the time of sampling in July 2014. She had 9 dental amalgams emplaced between July 1996 and April 1997 and decided to have them removed gradually after surgery for ablation of a salivary gland affected by a benign tumor in 1997. Six amalgams were removed without any precautions between 1997 and 2004. In 1999, she was afflicted by a thyroid cyst. In July 2012, removal of two more amalgams without precautions coincided with the onset of multiple chemical sensitivity (MCS) with symptoms of tingling in the feet, painful Achilles tendons, vertigo, difficulty in standing, mouth ulcers, and painful shoulders, knees, arms and feet. These symptoms did not occur simultaneously but came and went periodically over several months. The last amalgam was removed without precautions on 31 January 2013 and within two hours the individual felt abdominal vibrations and experienced dryness of eyes. Since that date, vibrations radiating from the pubis to the head, pain in various parts of her body, and intense tiredness have been ongoing. The negative symptoms increase after exposure to common and unrelated chemicals (household detergents, perfumes and fragrances, solvents, medical drugs, for example). Dental pain in both jaws, specifically around the sites of amalgam extraction, and gum bleeding continue.

Diagnosis of apparent MCS syndrome led the individual to suspect mercury contamination from dental amalgams, and so mercury quantification was performed in blood and urine in August 2012 and May 2014. Both fluids had concentrations below $1 \mathrm{ng} / \mathrm{mL}$ (Laboratoire Cerba, Cergy-Pontoise, France). Mercury in sections of hair from root to tip was measured in June 2014 (Table S3).

Table S3. Hair total mercury analysis of individual \#7. ${ }^{\mathrm{a}}$

\begin{tabular}{lll}
\hline Length from root $(\mathrm{cm})$ & $\begin{array}{l}\text { Estimated period of } \mathrm{Hg} \\
\text { deposition in hair }{ }^{\mathrm{b}}\end{array}$ & $\begin{array}{l}\mathrm{Hg} \text { concentration } \\
(\mathrm{ng} / \mathrm{mg})\end{array}$ \\
\cline { 1 - 1 } $\begin{array}{l}\text { June 2014 } \\
1-2\end{array}$ & May 2014 & 0.21 \\
$7-8$ & January 2014 & 0.15 \\
$21.5-22.5$ & January-February 2013 & 0.20 \\
$29-30$ & June-July 2012 & 0.23 \\
\hline
\end{tabular}

${ }^{a}$ Analysis performed in the Arcachon Marine Station from hair collected on June 25, 2014.

${ }^{\mathrm{b}}$ A hair growth rate of $1.3 \mathrm{~cm}$ per month was used to estimate the period of $\mathrm{Hg}$ deposition.

The quantification of mercury in saliva was performed from February to May 2014 (Table S4).

Table S4. Total mercury analysis in saliva of individual \#7

\begin{tabular}{ll}
\hline Date & $\begin{array}{l}\mathrm{Hg} \text { concentration } \\
(\mathrm{ng} / \mathrm{mL})\end{array}$ \\
\cline { 1 - 1 } 25 February 2014 & 1.6 \\
28 February 2014 & 2.4 \\
30 March 2014 & 2.6 \\
23 May 2014 & 4.8 \\
30 May 2014 & 2.0 \\
\hline
\end{tabular}




\section{S2. Materials}

\section{S2.1 Natural hair and hair with added mercury}

Hair was washed with $0.1 \mathrm{M} \mathrm{HCl}^{3}$ dried overnight, and stored in plastic sample bags. All reagents used for mercury sorption and complexation were analytical grade, and Milli-Q water was used throughout. Stock solutions of $10^{-4} \mathrm{M} \mathrm{Hg}$ were prepared using the following standard compounds: $\mathrm{Hg}\left(\mathrm{ClO}_{4}\right)_{2}$ for $\mathrm{Hg}^{2+}$ sorption, $\mathrm{CH}_{3} \mathrm{HgOH}$ for $\mathrm{MeHg}^{+}$sorption, and thimerosal $\left(\mathrm{C}_{9} \mathrm{H}_{9} \mathrm{HgNaO}_{2} \mathrm{~S}\right)$ for $\mathrm{EtHg}^{+}$sorption. Finely cut hair was reacted with mercury solutions in Savillex perfluoroalkoxy alkane (PFA) jars for 20 days at $\mathrm{pH} 6\left(\mathrm{Hg}^{2+}\right.$ and $\left.\mathrm{MeHg}^{+}\right)$and $\mathrm{pH} 7.4\left(\mathrm{EtHg}^{+}\right)$. Adjustment to $\mathrm{pH} 6$ was made with a $0.1 \mathrm{M}$ acetate buffer $\left(0.1 \mathrm{M} \mathrm{CH}_{3} \mathrm{COOH} / \mathrm{CH}_{3} \mathrm{COONa}\right)$ and to pH 7.4 with $0.01 \mathrm{M} \mathrm{NaOH}$. Mercury concentration in hair was measured in triplicate with an AMA-254 mercury analyzer following established procedure. ${ }^{4}$ The detection limit was $0.01 \mathrm{ng}$ $\mathrm{Hg}$, the precision $10 \%$, and the accuracy confirmed from analysis of the reference material in human hair IAEA-085 (determined values: $22.1 \pm 2.2 \mathrm{ng} \mathrm{Hg} \mathrm{mg}^{-1}$ dry weight; recommended value: $23.2 \mathrm{ng} \mathrm{Hg} \mathrm{mg}{ }^{-1}$ dry weight with a 95\% confidence interval of $22.4-24 \mathrm{ng} \mathrm{Hg} \mathrm{mg}^{-1}$ ). For HRXANES measurements, each sample of finely cut natural or reacted hair was mixed with boron nitride, pressed into pellets, placed in a polyether ether ketone (PEEK) holder, sealed with poly (4,4'-oxydiphenylene-pyromellitimide) (Kapton) tape, and stored in a plastic desiccator cabinet. The single strands of hair from individual \#7 were mounted on Kapton tape.

\section{S2.2. References for HR-XANES}

The nature of mercury bonding was determined by comparing hair spectra with a database for model compounds ${ }^{5,6}$ that included new spectra for $\mathrm{Hg}, \mathrm{MeHg}$, and EtHg complexes with Lcysteine, L-cystine, and human serum albumin (HSA). All solutions used to prepare the new reference complexes were deoxygenated by boiling and then saturated with argon. $10 \mathrm{mM}$ stock solutions of $\mathrm{MeHgOH}, \mathrm{Hg}\left(\mathrm{ClO}_{4}\right)_{2}$, and thimerosal were used as the source of mercury. $\mathrm{Hg}^{2+}$ complexes with L-cysteine $\left(\mathrm{Hg}(\mathrm{Cys})_{2}\right)$ and human serum albumin $(\mathrm{Hg}-\mathrm{HSA})$ were prepared at $[\mathrm{Hg}]=0.5 \mathrm{mM}$ and a $\mathrm{Hg}$ :ligand ratio of 1:2. Methylmercury $(\mathrm{MeHg})$ and thimerosal (THI) complexes with cysteine (MeHg-Cys, Thi-Cys) and human serum albumin (MeHg-HSA, ThiHSA), and a $\mathrm{Hg}^{2+}$ complex with cystine, were prepared at $[\mathrm{Hg}]=0.5 \mathrm{mM}$ and a $\mathrm{Hg}$ :ligand ratio of 1:1. A total of $150 \mu \mathrm{L}$ of each complex solution was placed in a PEEK holder designed for solutions. The holder was then immediately frozen in liquid nitrogen $\left(\mathrm{LN}_{2}\right)$, and stored in a $\mathrm{LN}_{2}$ Dewar until its transfer into the liquid helium (LHe) cryostat of the beamline for measurement. All model complexes were prepared less than three weeks before the X-ray absorption experiment. Nanoparticulate $\beta-\mathrm{HgS}$ was synthesized previously at room temperature from a $\mathrm{Hg}$-(L-Cys-OEt) 2 complex aged for 80 days in contact with air, and characterized by powder X-ray diffraction and HR-XANES. ${ }^{5}$

\section{S3. Deprotonation of the amide group}

S3.1. Deprotonation of the amide group of the peptide chain in the presence of $\mathrm{MeHg}^{+}$

Deprotonation calculations were performed on the GlyCysGly oligopeptide model. The $\mathrm{MeHg}^{+}$ion binds strongly to the cysteine thiolate group forming a complex of type $\mathrm{MeHgSR}$, here 
denoted $\mathrm{MeHg}$ [GlyCysGly]. This complex may further interact with an adjacent amide group and bind it in its deprotonated form $-\mathrm{N}^{(-)}-$. The new complex is denoted herein $\mathrm{MeHg}[\mathrm{GlyCysGly}]^{-1}$. Its optimized structure is given in Figure S6a. The deprotonation reaction can be described as:

$$
\mathrm{MeHg}[\text { GlyCysGly }] \rightarrow \mathrm{MeHg}[\text { GlyCysGly }]^{-1}+\mathrm{H}^{+}
$$

The calculated Gibbs free energy of (1) is $\Delta G=G\left(\mathrm{MeHg}[\mathrm{GlyCysGly}]^{-1}\right)+G\left(\mathrm{H}^{+}\right)-$ $G(\mathrm{MeHg}[\mathrm{GlyCysGly}])=24.2 \mathrm{kcal} \mathrm{mol}^{-1}$, and the $\mathrm{pKa}$ of the amide group in the presence of $\mathrm{MeHg}^{+}$, as calculated from $\mathrm{pKa}=0.43 \Delta G / \mathrm{RT}$, is 17.5 . This is a high value indicating that the deprotonation is thermodynamically forbidden. For an efficient deprotonation to occur at neutral $\mathrm{pH}$, one should have $\mathrm{pKa} \leq 7$, that is $\Delta G \leq 9.8 \mathrm{kcal} \mathrm{mol}^{-1}$. The difference with respect to the actual theoretical value is too large to be attributed to the computational uncertainty.

\section{S3.2. Deprotonation of the amide group of the peptide chain in the presence of $\mathbf{H g}^{\mathbf{2 +}}$}

The possibility of deprotonation of the amide group in the presence of inorganic mercury was examined for the case of the free $\mathrm{Hg}^{2+}$ cation (reaction 2), and for the case of $\mathrm{Hg}^{2+}$ bound to one thiolate (reaction 3). In the first case, the interaction with the oligopeptide model GlyCysGly gives the complex represented in Figure S9a according to the deprotonation reaction:

$$
\mathrm{Hg}[\text { GlyCysGly }]^{+1} \rightarrow \mathrm{Hg}[\text { GlyCysGly }]+\mathrm{H}^{+}
$$

The theoretical Gibbs free energy of reaction is $-0.5 \mathrm{kcal} \mathrm{mol}^{-1}$, which corresponds to a pKa value of -0.4. Hence the deprotonation process is thermodynamically extremely favored. However, the occurrence of a bidentate $\mathrm{Hg}\left[\mathrm{SR}+\mathrm{N}^{(-)}\right]$coordination is unlikely because $\mathrm{Hg}^{2+}$ binds to two thiolate ligands.

When $\mathrm{RSHg}^{+}$interacts with GlyCysGly, a complex $\mathrm{RSHg}$ [GlyCysGly] of the type $\mathrm{Hg}[2 \mathrm{SR}+\mathrm{NH}]$ is formed which may lose an amide proton to give the complex $\mathrm{RSHg}[\mathrm{GlyCysGly}]^{-}$ ${ }^{1}$ of the type $\mathrm{Hg}\left[2 \mathrm{SR}+\mathrm{N}^{(-)}\right]$(Figure $\mathrm{S} 9 \mathrm{~b}$ ). The corresponding reaction equation is given by:

$$
\mathrm{RSHg}[\mathrm{GlyCysGly}] \rightarrow \mathrm{RSHg}[\mathrm{GlyCysGly}]^{-1}+\mathrm{H}^{+}
$$

which has a calculated Gibbs free energy of $19.9 \mathrm{kcal} \mathrm{mol}^{-1}$ and a theoretical pKa value of 14.3. This complex would only form at high alkaline $\mathrm{pH}$. This conclusion is yet more valid if $\mathrm{Hg}$ forms a bis-chelate with two deprotonated amide groups, as represented in Figure S8d. 


\section{S4. Figures}
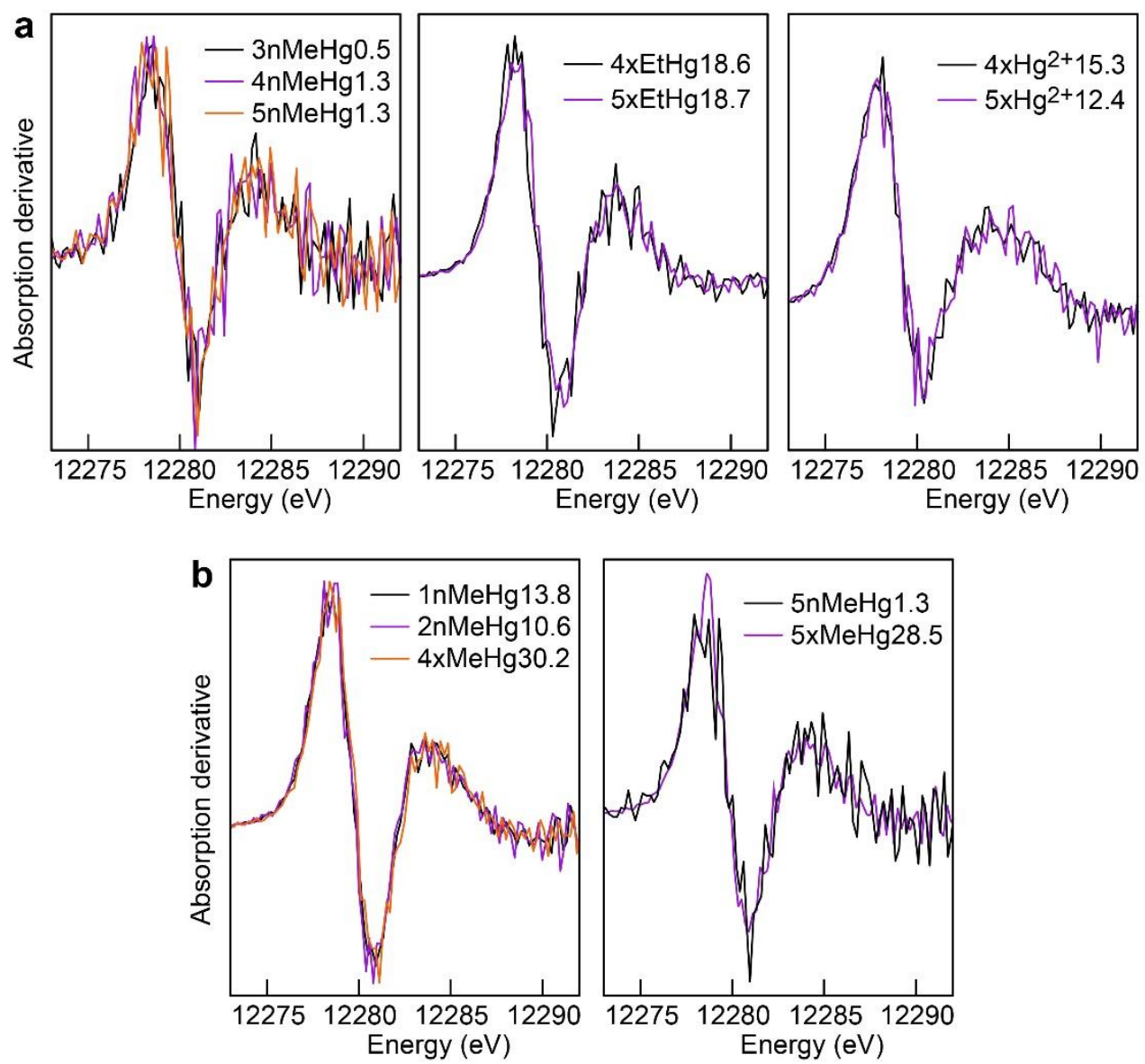

Figure S1. First derivatives of normalized HR-XANES spectra $(\mathrm{d} \mu / \mathrm{d} E)$. (a) Overlay plots of derivatives from hair exposed to $\mathrm{MeHg}$, EtHg, and $\mathrm{Hg}^{2+}$ show that the HR-XANES spectra are identical for each type of mercury source, and thereby provide unique signatures of the source of mercury in hair. (b) Overlay plots of derivatives from hair endogenously (1nMeHg13.8, 2nMeHg10.6, 5nMeHg1.3) and exogenously (4xMeHg30.2, 5xMeHg28.5) exposed to methylmercury showing that the form of $\mathrm{Hg}$ in hair is independent of the mode of exposure. 

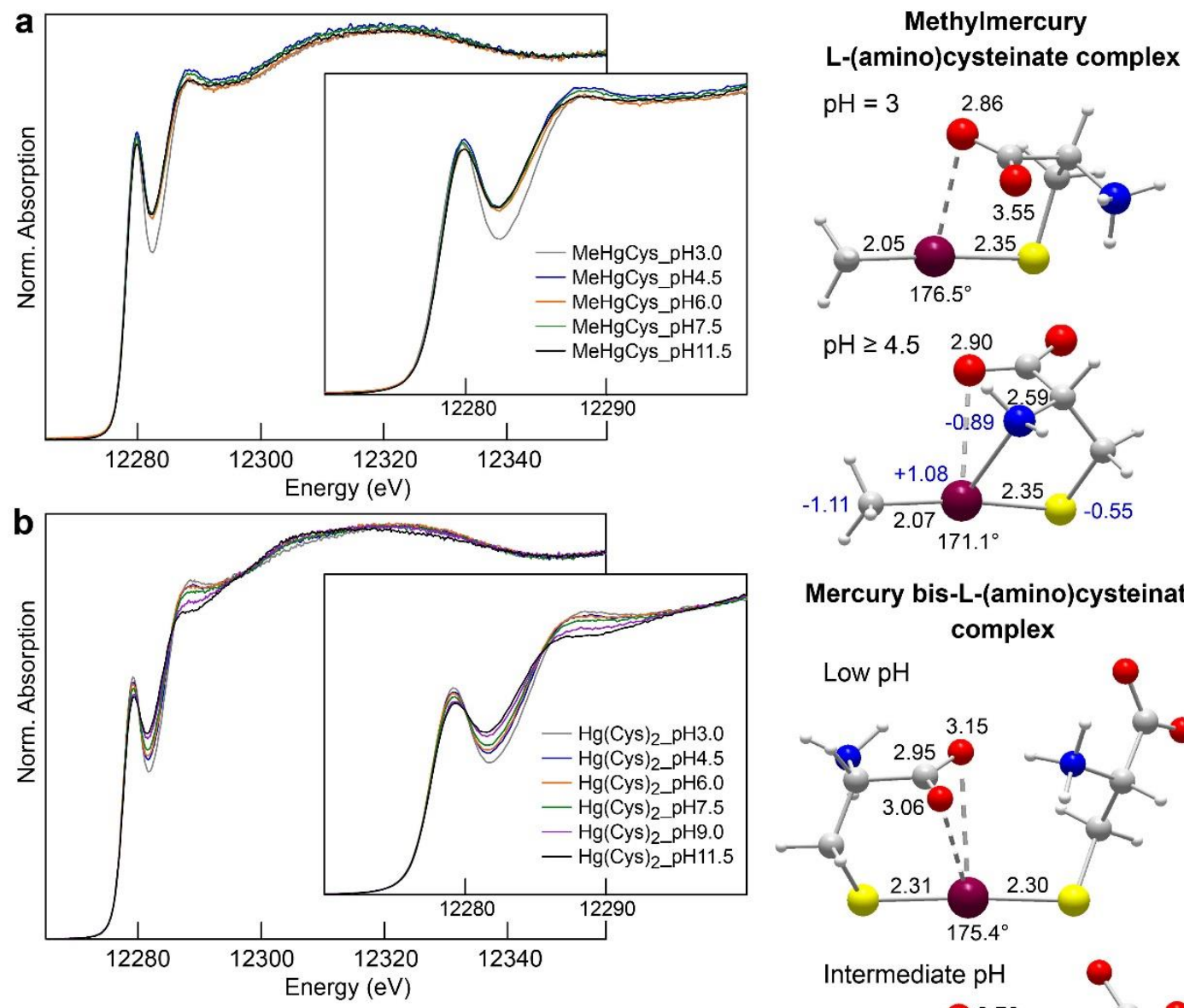

\section{Mercury bis-L-(amino)cysteinate} complex
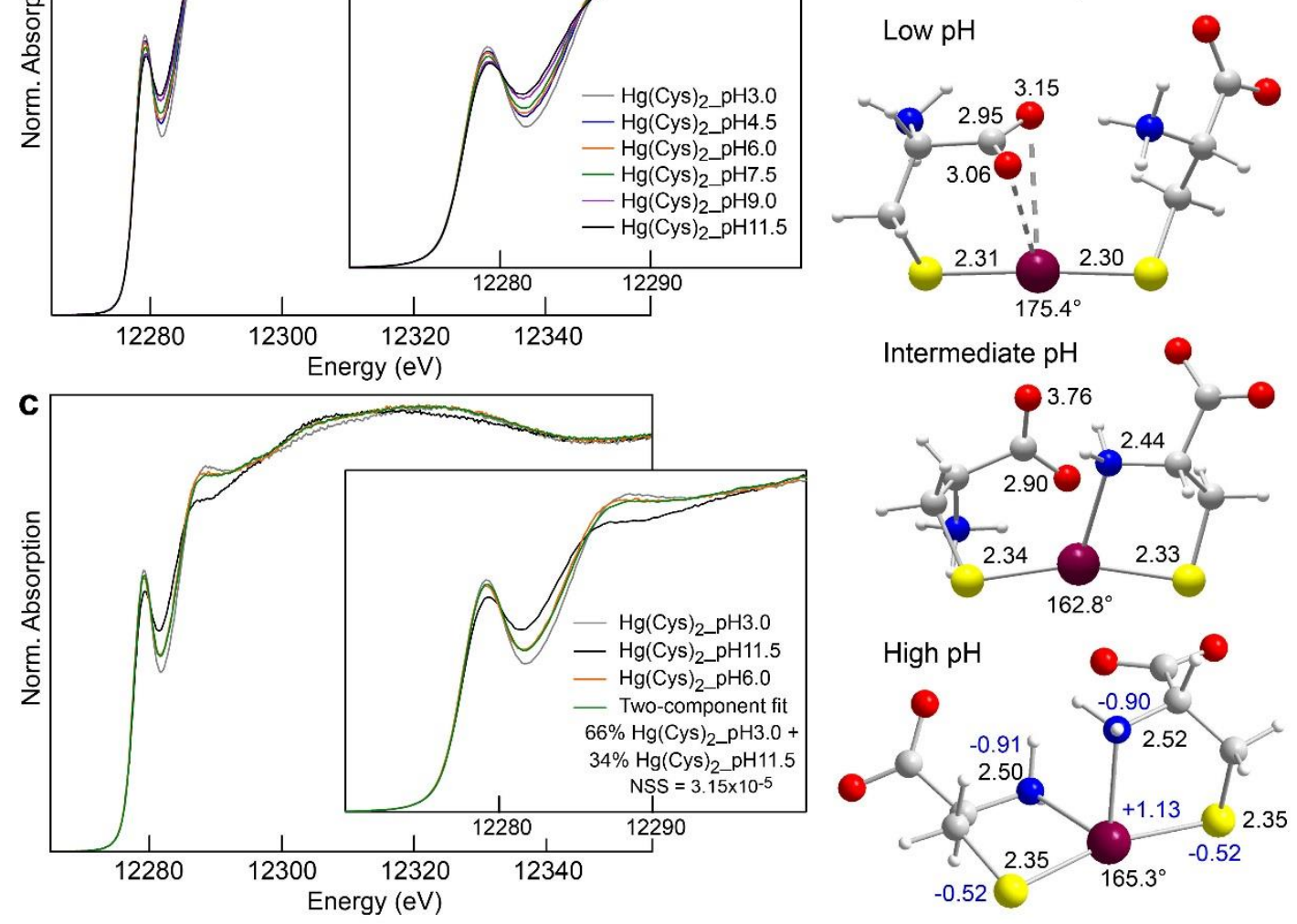

Figure S2. Hg L3-edge HR-XANES spectra of the methylmercury L-(amino)cysteinate complex (MeHgCys) (a) and mercury bis-L-(amino)cysteinate complex $\left(\mathrm{Hg}(\mathrm{Cys})_{2}\right)$ (b) as a function of $\mathrm{pH}$. In $\mathrm{MeHgCys}$, the amine groups are all deprotonated starting at $\mathrm{pH} 4.5\left(\mathrm{MeHg}\left[\mathrm{SR}+\mathrm{NH}_{2}\right]\right.$ coordination). In contrast, deprotonation spans a $\mathrm{pH}$ range of about 4.5 to $11 \mathrm{for} \mathrm{Hg}(\mathrm{Cys}) 2$. (c) Principal component analysis ${ }^{7}$ indicates that the $\mathrm{Hg}(\mathrm{Cys})_{2}$ spectral series can be described with only two components, which we confirmed by reconstructing the $\mathrm{pH} 6.0$ spectrum with a linear combination of the $\mathrm{pH} 3.0\left(\mathrm{Hg}[\mathrm{SR}]_{2}\right.$ coordination) and $\mathrm{pH} 11.5\left(\mathrm{Hg}\left[\mathrm{SR}+\mathrm{NH}_{2}\right]_{2}\right.$ coordination) endmembers. However, the system may well be a pseudobinary, in which $\mathrm{Hg}\left[(\mathrm{SR})_{2}+\mathrm{NH}_{2}\right]$ 
coordination coexists with the two others at intermediate $\mathrm{pH}$, because the two amine groups from a $\mathrm{Hg}(\mathrm{Cys})_{2}$ complex are unlikely to deprotonate simultaneously. A case in point is the bis-chelate of histidine with $\mathrm{Cu}$, in which the two chelates fold in sequence as $\mathrm{pH}$ increases leading to coexisting conformers ${ }^{8-10}$ Bond lengths are in angstroms, and bond angles are in black. Atomic charges, in units of elementary charge e and calculated by natural population analysis (NPA) ${ }^{11}$ are in blue. Dark red, $\mathrm{Hg}$; yellow, S; blue, N; red, O; gray, C; light gray, $\mathrm{H}$.
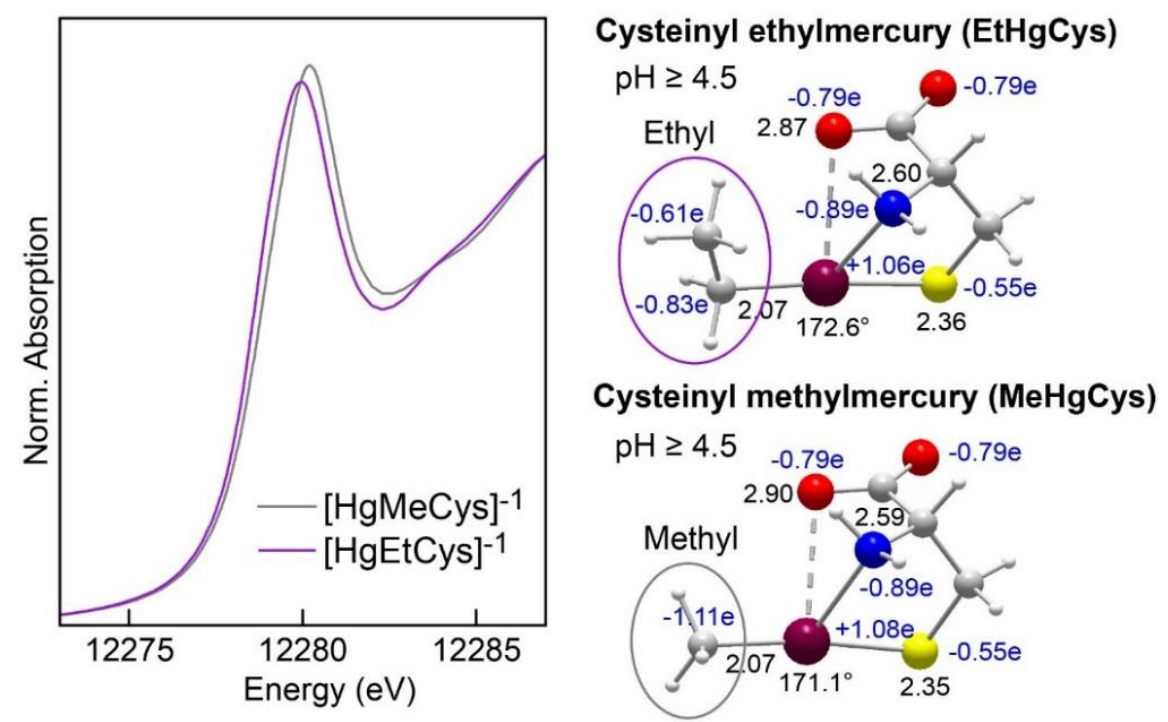

Figure S3. Sensitivity of the near-edge absorption peak to the nature of the alkyl ligand. The geometries of the EtHgCys and MeHgCys complexes were optimized by MP2 /TZVP-ecp calculations, ${ }^{6,12}$ and the atomic charges (in units of elementary charge e) were calculated by natural population analysis (NPA). ${ }^{6,}{ }^{11}$ The net charge of the two complex is -1 . Bond lengths are in angstroms, and bond angles are in black. Dark red, Hg; yellow, S; blue, N; red, O; gray, C; light gray, $\mathrm{H}$.

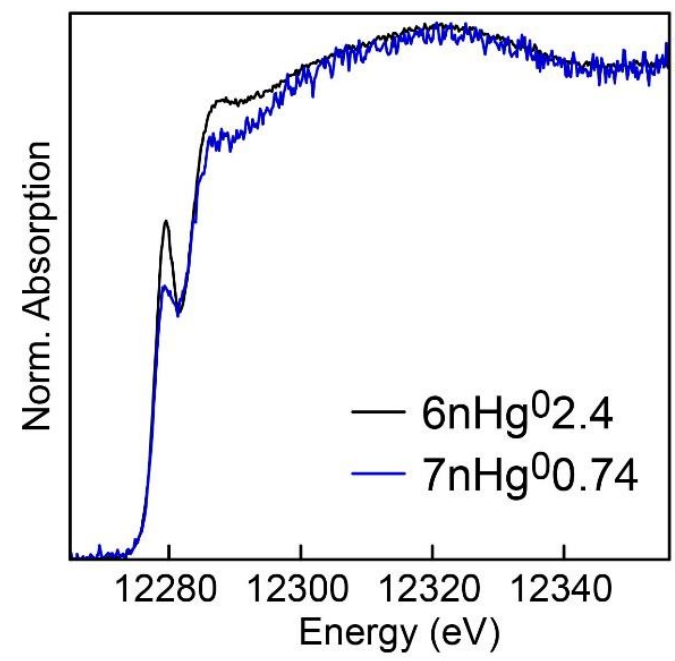

Figure S4. Hg L $\mathrm{L}_{3}$-edge HR-XANES spectra of hair containing endogenous mercury from dental amalgams (Table 1). At the lowest concentration of $0.74 \mathrm{ng} \mathrm{Hg} / \mathrm{mg}$ hair $\left(7 \mathrm{xHg}^{0} 0.74\right)$, long 
measuring times at LHe temperature $(10 \mathrm{~K})$ typically causes the signal amplitude to decrease in intensity as a result of $\mathrm{X}$-ray beam-damage. The single hair strand was only 80 microns thick, and therefore weakly absorbing at the energy of the $\mathrm{Hg} \mathrm{X}$-ray absorption $\mathrm{L}_{3}$-edge $(12.3 \mathrm{kV})$, which required repeated analysis at the hot spot location for over 7.5 hours. In comparison, no radiation damage was observed for sample $6 \mathrm{xHg}^{0} 2.4$ because multiple spectra were recorded for $15 \mathrm{~s}$ at different pristine positions on a $2.5 \mathrm{~mm}$-thick pellet of hair. The $7 \mathrm{xHg}^{0} 0.74$ spectrum shows, however, strong similarity with the spectrum of $6 \mathrm{xHg}^{0} 2.4$ in terms of positions and relative intensities of peaks and broad pattern at higher energies, which suggests that mercury was initially in the same form in the two samples. The $\mathrm{Hg}$ concentration of the hot-spot $(0.74 \mathrm{ng} / \mathrm{mg})$ was calculated from the average hair concentration $(0.2 \mathrm{ng} / \mathrm{mg})$ and the ratio of the $\mathrm{Hg}$ L $\alpha$ counts on and away from the spot (Figure 1). This ratio is proportional to the $\mathrm{Hg}$ concentration because the hair is weakly absorbing (i.e., there is no overabsorption effect. ${ }^{13}$ ) The transmission of 80 microns of keratin at the $\mathrm{Hg}$ L $\alpha$ energy $(10 \mathrm{keV})$ is 0.90 . Taking an average linear mass of $50 \mathrm{ng} / \mathrm{cm}$ for hair ${ }^{14}$ the hot-spot has a mass of $2.5 \mathrm{ng}$. In comparison, chromatographic-based analyses for $\mathrm{MeHg}$ and $\mathrm{EtHg}$ require $10 \mathrm{mg}^{15}$ or more ${ }^{16}$ of hair.

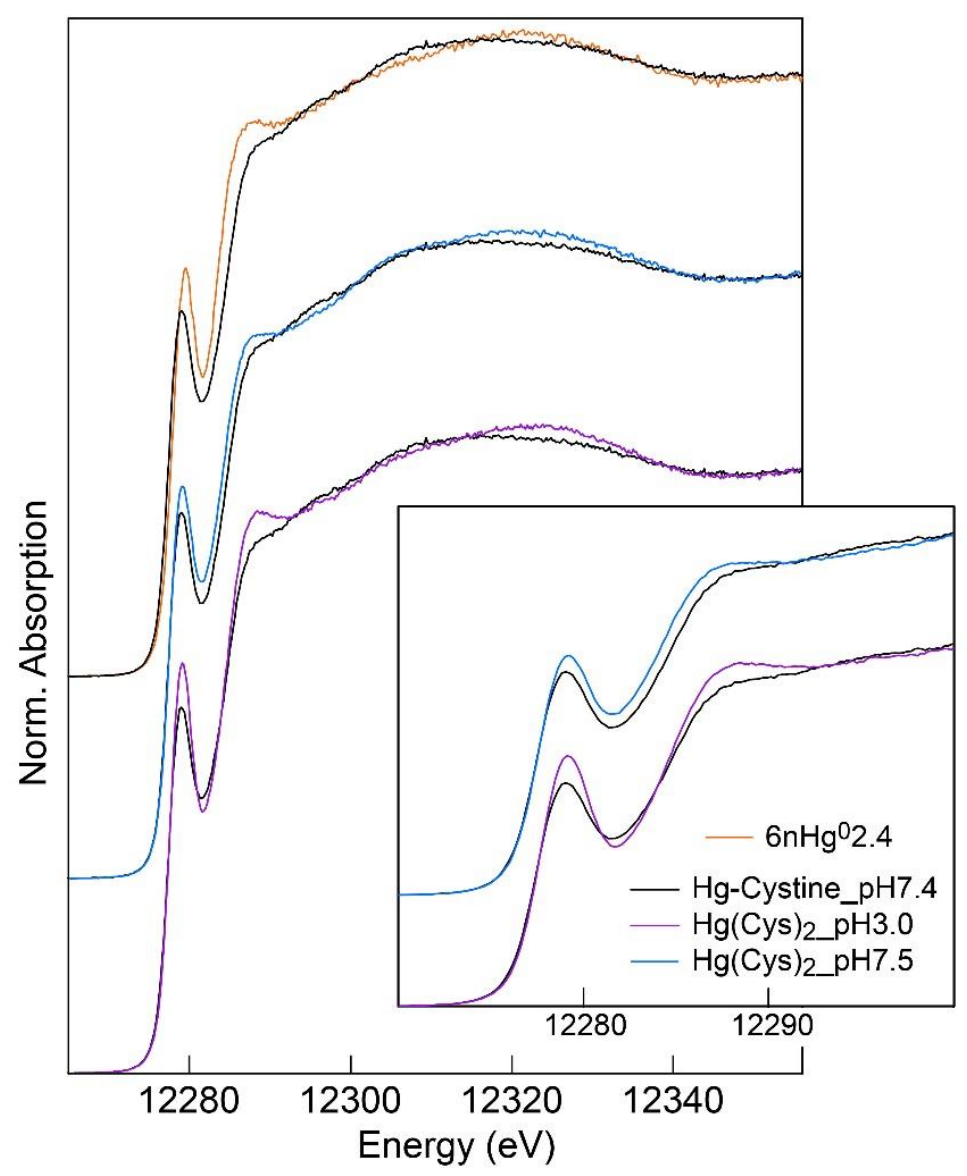

Figure. S5. $\mathrm{Hg} \mathrm{L}_{3}$-edge HR-XANES spectra of hair $6 \mathrm{xHg}^{0} 2.4$ from dental amalgam and mercury complexes with cystine and cysteine. The two ligands produce different signatures. 


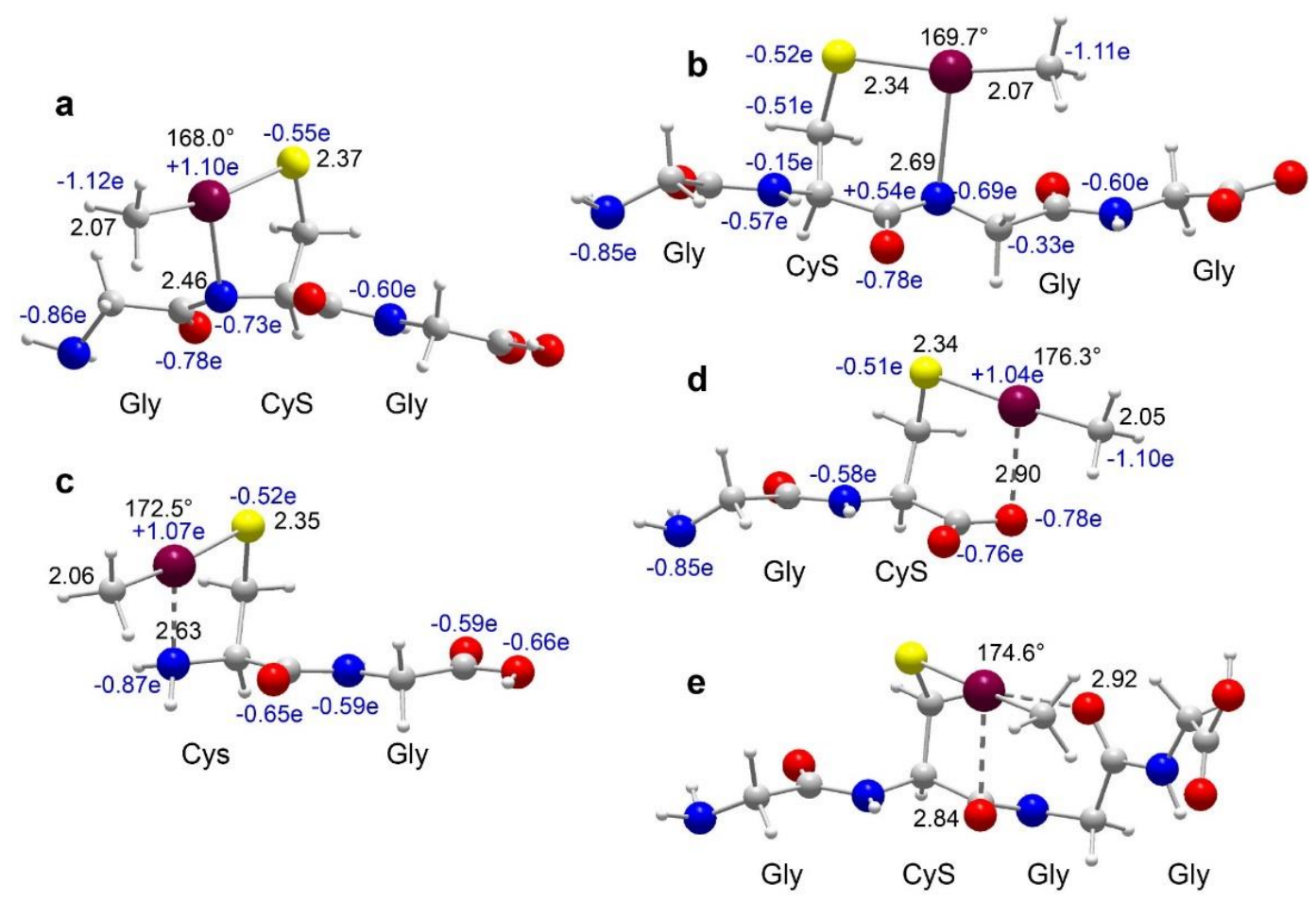

Figure. S6. Unsuitable intramolecular binding sites of methylmercury in hair proteins (MP2/TZVP-ecp optimization). (a,b) Five-member (a) and six-member (b) ring chelates with a deprotonated amide ligand $\left(\mathrm{N}^{(-)}\right)$from the peptide backbone. Although the $\mathrm{Hg}-\mathrm{N}$ distance and $\mathrm{Me}-$ $\mathrm{Hg}-\mathrm{S}$ angle are compatible with HR-XANES results, energetics calculations show that methylmercury is unlikely to dissociate the $\mathrm{N}-\mathrm{H}$ bond. (c) $\mathrm{MeHg}$ binding to a hypothetical $\mathrm{N}$ terminal cysteine residue. The $\mathrm{Hg}-\mathrm{N}$ distance and $\mathrm{Me}-\mathrm{Hg}-\mathrm{S}$ angle are also consistent with $\mathrm{Hg}-$ XANES results, but this termination does not seem to exist in hair protein ${ }^{17-19}$. (d) MeHg bonding to a carboxy-terminal cysteine residue. The $\mathrm{Hg}$... O contact is too weak to bend the Me-Hg-S angle. (e) Mercury also interacts weakly with backbone carbonyl oxygens. Bond lengths are in angstroms, and bond angles are in black. Atomic charges, in units of elementary charge e and calculated by natural population analysis (NPA), ${ }^{11}$ are in blue. Dark red, $\mathrm{Hg}$; yellow, S; blue, N; red; O, gray, C; light gray, $\mathrm{H}$.

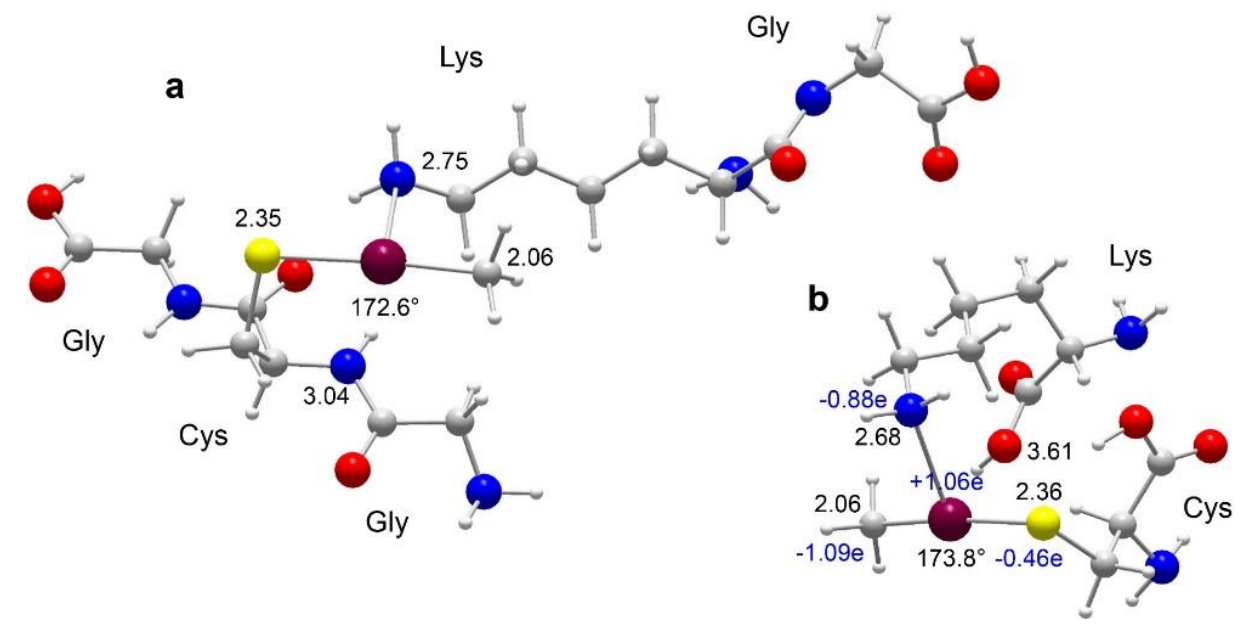


Figure. S7. Suitable intermolecular binding sites of methylmercury in hair proteins (MP2/TZVPecp optimization). Bond lengths are in angstroms, and bond angles are in black. Atomic charges, in units of elementary charge e and calculated by natural population analysis (NPA), ${ }^{11}$ are in blue. Dark red, Hg; yellow, S; blue, N; red, O; gray, C; light gray, H. The Hg-N distance is 0.09 to 0.16 $\AA$ longer and the $\mathrm{Me}-\mathrm{Hg}-\mathrm{S}$ angle correspondingly 1 to $3^{\circ}$ flatter in these models than for $\mathrm{MeHgCys}$ at $\mathrm{pH}>4.5$, seen in Figure 3B by a sharpening of the hair spectrum.
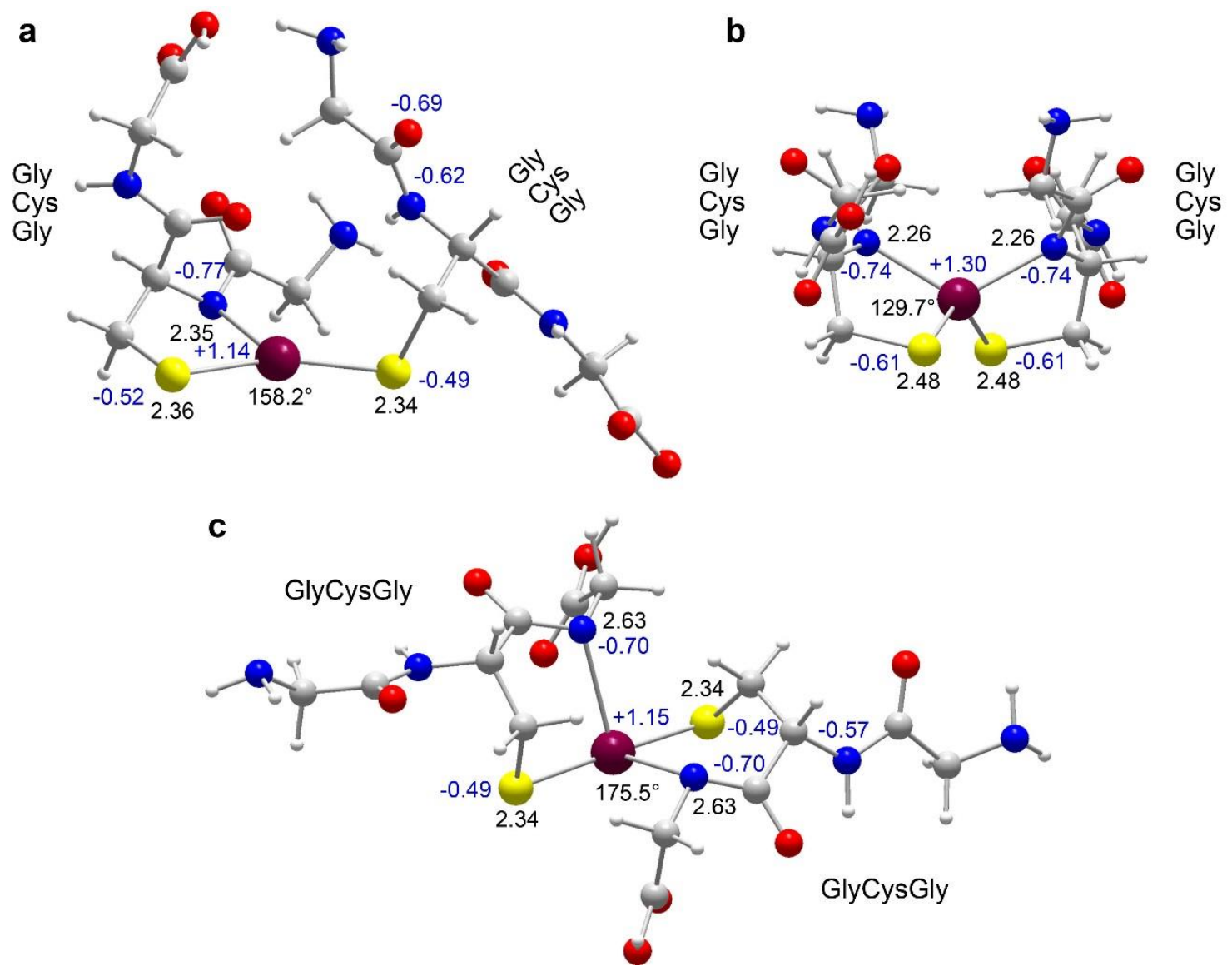

Figure. S8. Unsuitable intermolecular binding of mercury to deprotonated amide group from RSCO-NH-SR peptide bond in hair proteins (MP2/TZVP-ecp optimization). (a) Tridentate $\mathrm{Hg}\left[(\mathrm{SR})_{2}+\mathrm{N}^{(-)}\right]$coordination with a five-member ring chelation of $\mathrm{Hg}$ between the sulfhydryl group and the deprotonated cysteinyl peptide nitrogen from a Gly-CO-N-Cys-CO-NH-Gly sequence. (b) Bisphenoidal $\mathrm{Hg}\left[\mathrm{SR}+\mathrm{N}^{(-)}\right]_{2}$ coordination with two GlyCysGly oligopeptide strands. (c) Bisphenoidal $\mathrm{Hg}\left[\mathrm{SR}+\mathrm{N}^{(-)}\right]_{2}$ coordination with two six-member ring chelates of $\mathrm{Hg}$ between the sulfhydryl group and the deprotonated glycylpeptide nitrogen from a Gly-CO-NH-Cys-CO-N-Gly sequence. Complexes $(\mathrm{a}, \mathrm{b})$ have short $\mathrm{Hg}-\mathrm{N}$ distances incompatible with HR-XANES results, and the S-Hg-S angle of complex (c) is not bent. Bond lengths are in angstroms, and bond angles are in black. Atomic charges, in units of elementary charge e and calculated by natural population analysis (NPA), ${ }^{11}$ are in blue. Dark red, Hg; yellow, S; blue, N; red, O; gray, C; light gray, H. 

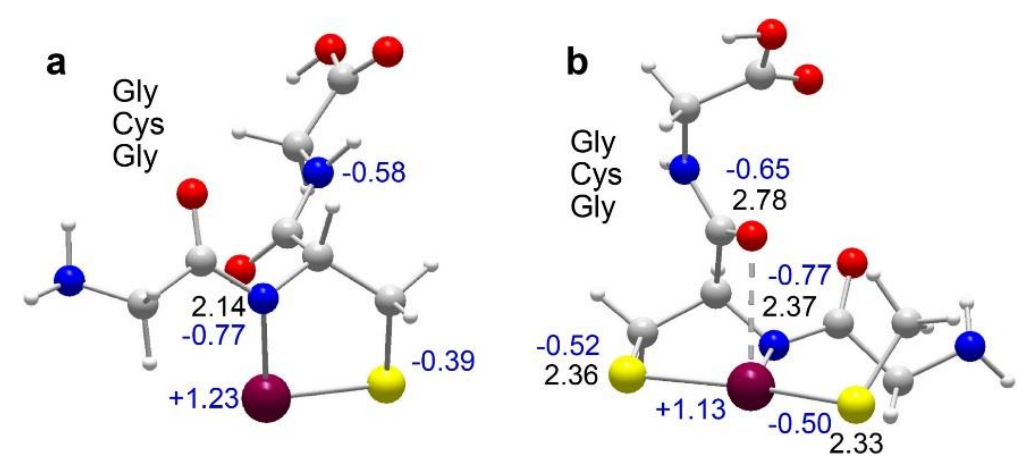

Figure. S9. a) Computed $\mathrm{Hg}[$ GlyCysGly] complex used in Equation (2) to calculate the $\Delta G$ of deprotonation of the amide group from the Gly-CO-NH-Cys peptide bond by $\mathrm{Hg}^{2+}$. b) Computed RSHg[GlyCysGly] $]^{-1}$ complex (with $\mathrm{R}=\mathrm{Me}$ ) used in Equation (3) to calculate the $\Delta G$ of deprotonation of the amide group from the Gly-CO-NH-Cys peptide bond by $\mathrm{RSHg}^{+}$. Bond lengths are in angstroms. Atomic charges, in units of elementary charge e and calculated by natural population analysis (NPA), ${ }^{11}$ are in blue. Dark red, $\mathrm{Hg}$; yellow, S; blue, N; red; O, gray, C; light gray, $\mathrm{H}$.

\section{S5. References}

(1) Bourdineaud, J. P.; Durrieu, G.; Sarrazin, S. L. F.; da Silva, W. C. R.; Mourao, R. H. V.; de Oliveira, R. B., Mercurial exposure of residents of Santarem and Oriximina cities (Para, Brazil) through fish consumption. Environ. Sci. Pollut. Res. 2015, 22, 12150-12161.

(2) Woods, J. S., Altered porphyrin metabolism as a biomarker of mercury exposure and toxicity. Can. J. Physiol. Pharmacol. 1996, 74, 210-215.

(3) Morton, J.; Carolan, V. A.; Gardiner, P. H. E., Removal of exogenously bound elements from human hair by various washing procedures and determination by inductively coupled plasma mass spectrometry. Anal. Chim. Acta 2002, 455, 23-34.

(4) Díez, S.; Montuori, P.; Querol, X.; Bayona, J. M., Total mercury in the hair of children by combustion atomic absorption spectrometry (Comb-AAS). J. Anal. Toxicol. 2007, 31, 144-149.

(5) Manceau, A.; Lemouchi, C.; Enescu, M.; Gaillot, A.-C.; Lanson, M.; Magnin, V.; Glatzel, P.; Poulin, B. A., et al., Formation of mercury sulfide from $\mathrm{Hg}(\mathrm{II})$-thiolate complexes in natural organic matter. Environ. Sci. Technol. 2015, 49, 9787-9796.

(6) Manceau, A.; Lemouchi, C.; Rovezzi, M.; Lanson, M.; Glatzel, P.; Nagy, K. L.; GautierLuneau, I.; Joly, Y., et al., Structure, bonding, and stability of mercury complexes with thiolate and thioether ligands from high-resolution XANES spectroscopy and first-principles calculations. Inorg. Chem. 2015, 54, 11776-11791.

(7) Manceau, A.; Marcus, M.; Lenoir, T., Estimating the number of pure chemical components in a mixture by X-ray absorption spectroscopy. J. Synchrotron Radiat. 2014, 21, 1140-1147.

(8) Deschamps, P.; Kulkarrui, P. P.; Gautam-Basak, M.; Sarkar, B., The saga of copper(II)-Lhistidine. Coord. Chem. Rev. 2005, 249, 895-909.

(9) Mesu, J. G.; Visser, T.; Soulimani, F.; van Faassen, E. E.; de Peinder, P.; Beale, A. M.; Weckhuysen, B. M., New insights into the coordination chemistry and molecular structure of copper(II) histidine complexes in aqueous solutions. Inorg. Chem. 2006, 45, 1960-1971.

(10) Manceau, A.; Simionovici, A.; Lanson, M.; Perrin, J.; Tucoulou, R.; Bohic, S.; Fakra, S. C.; Marcus, M. A., et al., Thlaspi arvense binds $\mathrm{Cu}$ (II) as a bis-(L-histidinato) complex on root cell walls in an urban ecosystem. Metallomics 2013, 5, 1674-1684. 
(11) Glendening, E. D.; Landis, C. R.; Weinhold, F., NBO 6.0: Natural bond orbital analysis program. J. Comput. Chem. 2013, 34, 1429-1437.

(12) Enescu, M.; Manceau, A., High-level ab initio calculation of the stability of mercurythiolate complexes. Theor. Chem. Acc. 2014, 133, n 1457.

(13) Manceau, A.; Marcus, M. A.; Tamura, N., Quantitative speciation of heavy metals in soils and sediments by synchrotron X-ray techniques. In Applications of Synchrotron Radiation in LowTemperature Geochemistry and Environmental Science, Fenter, P. A.; Rivers, M. L.; Sturchio, N. C.; Sutton, S. R., Eds. Mineralogical Society of America: Washington, DC, 2002; Vol. 49, pp 341428.

(14) Legrand, M.; Passos, C. J. S.; Mergler, D.; Chan, H. M., Biomonitoring of mercury exposure with single human hair strand. Environ. Sci. Technol. 2005, 39, 4594-4598.

(15) Dórea, J. G.; Bezerra, V.; Fajon, V.; Horvat, M., Speciation of methyl- and ethyl-mercury in hair of breastfed infants acutely exposed to thimerosal-containing vaccines. Clin. Chim. Acta 2011, 412, 1563-1566.

(16) Gibicar, D.; Logar, M.; Horvat, N.; Marn-Pernat, A.; Ponikvar, R.; Horvat, M., Simultaneous determination of trace levels of ethylmercury and methylmercury in biological samples and vaccines using sodium tetra(n-propyl)borate as derivatizing agent. Anal. Bioanal. Chem. 2007, 388, 329-340.

(17) Shimomura, Y.; Aoki, N.; Rogers, M. A.; Langbein, L.; Schweizer, J.; Ito, M., Characterization of human keratin-associated protein 1 family members. J. Invest. Dermatol. Symp. Proc. 2003, 8, (1), 96-99.

(18) Lee, C. H.; Kim, M. S.; Chung, B. M.; Leahy, D. J.; Coulombe, P. A., Structural basis for heteromeric assembly and perinuclear organization of keratin filaments. Nature Struct. Mol. Biol. 2012, 19, 707-715.

(19) Strasser, B.; Mlitz, V.; Hermann, M.; Tschachler, E.; Eckhart, L., Convergent evolution of cysteine-rich proteins in feathers and hair. BMC Evol. Biol. 2015, 15, $\mathrm{n}^{\circ} 88$. 